\title{
Condição socioespacial e (i)mobilidade urbana como barreiras espaciais da classe trabalhadora periférica em São Paulo
}

Sandro Barbosa de Oliveira ${ }^{1}$

Resumo: Esse artigo é uma síntese de parte de minha tese de doutorado em que analiso a crise de mobilidade urbana vivenciada por trabalhadores(as) que habitam as periferias da metrópole de São Paulo a partir de sua condição socioespacial. Procuro demonstrar que tal condição está determinada pela tríplice segregação do espaço urbano socioespacial, étnico-racial e territorial/urbana - que se apresenta como mais uma camada da desigualdade urbana para maior parte da classe trabalhadora mediada pelo processo de urbanização rodoviarista, modelo de mobilidade predominante que está assentado na tríade industrial automotiva, petrolífera e construção civil que remodelaram a forma urbana de circulação nas grandes metrópoles brasileiras. Então, nesse artigo, analisamos como o tempo de deslocamento tem sido socialmente determinado por meio da experiência de trabalhadores(as) de baixa renda entrevistados (as) nos grupos focais, relacionando tais experiências à estrutura de transporte nos mapas de deslocamentos produzidos com dados da Pesquisa Origem-Destino de 2017 do Metrô de São Paulo e indicadores de renda nos territórios periféricos em comparação com o centro expandido da metrópole, ao evidenciar dinâmicas de deslocamentos distintas e a diferença entre a mobilidade ampla e a mobilidade restrita.

Palavras-chave: Condição socioespacial. Tríplice segregação. Urbanização rodoviarista. Mobilidade ampla. Mobilidade restrita.

\footnotetext{
${ }^{1}$ É cientista social, professor e educador popular. Doutor em Sociologia pelo IFCH UNICAMP, mestre em Ciências Sociais pela EFLCH UNIFESP e bacharel em Ciências Sociais pela FAFIL CUFSA. Pesquisador do Centro de Estudos Periféricos do IC UNIFESP e do Grupo Problemática Ambiental e Urbana da UNICAMP.
} 
Abstract: This article is a synthesis of part of my doctoral thesis in which I analyze the urban mobility crisis experienced by workers who inhabit the outskirts of the metropolis of São Paulo from their socio-spatial condition. I try to demonstrate that this condition is determined by the triple segregation of urban space - socio-spatial, ethnic-racial and territorial / urban - which presents itself as another layer of urban inequality for most of the working class mediated by the road urbanization process, a mobility model predominant that is based on the automotive, oil and civil construction industrial triad that remodeled the urban form of circulation in the great Brazilian metropolises. So, in this article, we analyze how commuting time has been socially determined through the experience of low-income workers interviewed in the focus groups, relating such experiences to the transport structure in the displacement maps produced with data from the 2017 Origin-Destination Survey of the São Paulo Metro and income indicators in peripheral territories compared to the expanded center of the metropolis, by evidencing different displacement dynamics and the difference between broad mobility and restricted mobility.

Keywords: Socio-spatial condition. Triple segregation. Highway urbanization. Broad mobility. Restricted mobility.

\section{Introdução}

A crise de mobilidade urbana vivenciada por habitantes das periferias da metrópole de São Paulo e das metrópoles brasileiras é oriunda de um longo processo de urbanização. Ela foi marcada pela desigualdade urbana via urbanização rodoviarista que prevaleceu enquanto projeto das classes dominantes oriunda do tripé de crescimento econômico global representado por indústrias petroleira, automobilística e da construção civil alicerçada no fordismo periférico, que determinou o desenho espacial de circulação de bens, serviços e trabalhadores nessas aglomerações urbanas e o padrão de deslocamento crescente por transporte individual nas últimas décadas. 
Isso tem provocado a individualização do acesso ao transporte que é um direito social fundamental que permite garantir o direito à cidade, devido às décadas de sucateamento das ferrovias e expansão relativa do transporte coletivo em favor da aceleração do tempo de rotação do capital das montadoras de veículos.

Tanto o transporte coletivo como o crescente transporte individual se converteram nas últimas décadas em mediadores fundamentais entre os momentos de produção e reprodução social da vida de quem habita a metrópole de São Paulo. Além das jornadas de trabalho e dos estudos que trabalhadores formais, informais e estudantes das periferias necessitam encarar cotidianamente, eles dispendem e são consumidos por um tempo de deslocamento que não é considerado como fator de desigualdade social nesse cotidiano vivido. Esse tempo de deslocamento representa mais que o dado numérico da Pesquisa Origem-Destino do Metrô de São Paulo (OD), ele significa parte do tecido da vida dessas pessoas que encara longos deslocamentos para ir e voltar de casa ao trabalho, escola ou universidades todos os dias úteis dessas atividades distribuídas e concentradas desigualmente no espaço urbano produzido que também é um espaço segregado e dividido.

O transporte coletivo em São Paulo é um dos mais caros do mundo e é mais precário nas periferias, onde vive a maioria dos trabalhadores de baixa renda que já lida com as condições precárias de trabalho e moradia. Então, com o objetivo de contribuir com a discussão das desigualdades urbanas nos Cadernos CEMARX, esse artigo apresenta uma breve exposição de parte de minha tese de doutorado intitulada "A condição socioespacial da classe trabalhadora: transporte e cotidiano da motilidade perversa na metrópole de São Paulo", desenvolvida no Instituto de Filosofia e Ciências Humanas da Universidade Estadual de Campinas (IFCH UNICAMP) na qual analisei a importância do transporte no cotidiano para entender as desigualdades que imperam na sociedade, uma vez que a mobilidade urbana tem sido precária e o tempo de deslocamento maior nas periferias. 
A mobilidade urbana, que se refere às possiblidades e facilidades de deslocamento de pessoas e bens na cidade, chegou ao ponto que beira a imobilidade na circulação por três aspectos: 1) "império do automóvel", que tem provocado imensos congestionamentos; 2) barreiras do alto custo do transporte coletivo, que impossibilita trabalhadores empregados e desempregados de circularem na metrópole; e 3) longos tempos de deslocamentos nos transportes públicos e coletivos, como uma condição cheia de barreiras espaciais para a reprodução da classe trabalhadora que habita as periferias de São Paulo.

Foi nessa problemática que analisamos a condição socioespacial da classe trabalhadora, ao destacar os diversos aspectos que compõem essa noção que permitem interpretar as causas das desigualdades sociais que se manifestam nesse espaço urbano no âmbito reprodução social por meio da produção e reprodução do espaço urbano. O ponto de partida da análise foi a tríplice segregação socioespacial, étnicoracial e urbana, as quais inter-relacionamos a condição espacial da classe trabalhadora que vive nas periferias constituída em maioria por proletários (as), pretos (as) e periféricos (as), cuja condição de vida está associada a precária reprodução decorrente de sua circulação e de seu tempo de deslocamento, ao situar o transporte e a mobilidade urbana no processo de circulação da acumulação capitalista de modo mais ampliado.

Esses padrões de deslocamento advêm da formação socioespacial brasileira que tem sido desigual, dependente e periférica no modo de produção capitalista, e que fez predominar na metrópole a separação entre localizações de moradias e empregos para os trabalhadores periféricos. A cidade e a metrópole são expressão da sociedade e se estruturaram pela divisão de classes sociais que é característica de sociedades em que predomina o processo de acumulação do capital, expandida ao espaço urbano que é produto do longo processo de urbanização que se converteu em produtor de desigualdades e dominação de classes pelo controle do tempo de deslocamento de

\begin{tabular}{l|l}
4 & Condição socioespacial e (i)mobilidade urbana...
\end{tabular} 
trabalhadores. Esse tempo, que não é visto como fator de desigualdade social, tem sido diferente para indivíduos de classes sociais distintas que habitam espaços diferenciados da metrópole e reproduzem modos de vidas de acordo com a classe que pertencem. Para muitos, os espaços que habitam e trabalham não são escolhas, mas condição de diferenciação de classe no processo social de consciência e, por esse motivo, não deve se tratado de modo homogêneo. Portanto, a noção de condição socioespacial da classe trabalhadora objetiva contribuir com o entendimento da indissociabilidade entre espaço-tempo-sociedade.

\section{A tríplice segregação do urbano: definições metodológicas da pesquisa e da exposição}

As periferias da metrópole de São Paulo nas últimas décadas têm sido o território de moradia e reprodução de maior parte da classe trabalhadora superexplorada com baixos salários e espoliada em suas condições de reprodução social no urbano. Suas condições de trabalho, vida e moradia, estudada e debatida em universidades, movimentos sociais e políticas públicas, refletem a importância de se interpretar, compreender e modificar os problemas oriundos dessa formação socioespacial desigual resultante da herança colonial, escravista e frações das classes dominantes concentradora de renda, poderes econômicos e políticos para sua reprodução de classe privilegiada, enquanto que a reprodução precária é vivida por trabalhadores que habitam as periferias das cidades e metrópoles brasileiras.

Um dos problemas fundamentais sobre a vida em metrópoles de economias dependentes relaciona-se ao transporte cotidiano de trabalhadores, mercadorias e serviços. Ao analisamos o processo de urbanização da sociedade para compreender o transporte, a mobilidade urbana e como o tempo de deslocamento tornou-se determinado pelo espaço produzido, partimos da caracterização do que designamos por condição socioespacial da classe trabalhadora, isto é, o deslocamento cotidiano pelas cidades e metrópoles tem sido determinado pela 
classe social de seus habitantes, o que significa dizer que a desigualdade socioespacial é resultado da segregação urbana que marca estruturalmente a vida social nesses territórios a partir de relações espaciais entre as diferentes classes.

A condição socioespacial da classe trabalhadora em São Paulo refere-se ao processo de produção e reprodução do espaço social decorrente do tipo de urbanização rodoviarista ${ }^{2}$ que predominou na formação brasileira a partir da década de 1950, com a chegada das grandes montadoras, com a consequente intensificação do modelo rodoviarista mediante a decisão de frações das classes dominantes desde os anos 1930 de que os investimentos públicos deveriam ser direcionados para esse tipo de mobilidade nas cidades brasileiras, ao provocar o crescimento do transporte individual em detrimento do transporte coletivo. Por essa razão direta, mobilidade e imobilidade urbana da classe trabalhadora têm um problema na origem nesse tipo urbanização, e com o seu desenvolvimento desigual por meio da segregação urbana que produziu e tem reproduzido cidades cada vez mais segregadas, o problema aparece na distância entre as classes sociais na reprodução social.

Mas por uma razão inversa, tanto o transporte coletivo como o crescente transporte individual se converteram nas últimas décadas em mediadores fundamentais entre produção e reprodução social da vida, cuja dinâmica entre a rede de transportes (fixo) e deslocamentos (fluxos), como indicou Eduardo Vasconcellos (2014), é essencial para entender o problema. Além das extensas jornadas de trabalho e estudos que trabalhadores formais, informais e estudantes que habitam as periferias das cidades necessitam encarar cotidianamente, eles dispendem e são consumidos por um tempo de deslocamento que não é considerado como fator de desigualdade pelas classes privilegiadas.

\footnotetext{
${ }^{2}$ A urbanização rodoviarista representa o modelo que predominou nas cidades com base no tripé: 1) indústria petroleira; 2) indústria automobilística; e 3) indústria da construção civil. Há um capítulo em minha tese de doutorado que analiso seus processos e determinações.
}

\begin{tabular}{l|l}
\hline 6 & Condição socioespacial e (i)mobilidade urbana...
\end{tabular} 
Então, para compreender aspectos dessa realidade da qual designamos por condição socioespacial na tese de doutorado na qual o espaço é parte das condições de vida e das desigualdades urbanas enfrentadas por indivíduos de diferentes classes sociais, é fundamental analisar os longos tempos de deslocamentos enfrentados por trabalhadores precários que realizam trabalhos manuais e longas jornadas como fator de diferenciação de classe. Para sua definição, nos referenciamos na noção de condição espacial de Ana Fani A. Carlos (2018), que definiu que: “[...] Desse modo, estabeleceu-se um ponto de partida possível: o espaço, tal qual pode ser apreendido pela Geografia, num movimento dialético que o definiria como condição, meio e produto da ação humana" (Carlos, 2018: p. 09). Todavia, para apreender tal desigualdade, analisamos as relações, contradições sociais e partimos da caracterização por meio de mapas e dados da OD-Metrô, além de entrevistas em grupos focais, ao definir a condição socioespacial ao longo desse artigo como o processo de diferenciação espacial por classe social.

Na Região Metropolitana de São Paulo (RMSP), território desse estudo, verifica-se as seguintes características: na figura $1^{3}$ a seguir, o município de São Paulo concentrava, em 2017, mais da metade da população da RMSP, com 11,7 milhões de habitantes e $64,1 \%$ dos empregos, o que provocava longos deslocamentos internos das demais sub-regiões para as localidades desses empregos para o centro da metrópole. A Sub-Região Sudeste vinha em seguida com 2,6 milhões de habitantes e era responsável por $11,6 \%$ dos empregos, depois a Sub-Região Oeste com 2,1 milhões de habitantes e 8,8\% dos empregos. A figura 2, por sua vez, representa a concentração de empregos no quadrante sudoeste e parte do centro expandido do município de São Paulo, centro da metrópole.

\footnotetext{
${ }^{3}$ A Figura 1 foi inspirada no mapa produzido pelo Movimento Cultural das Periferias no que tange o município de São Paulo. Esse mapa embasou a Lei de Fomento à Cultura das Periferias (Lei 16.496/2016).
} 
Figura 1: RMSP - Periferias, Subúrbios, Centro Expandido do Município de São Paulo e Sub-Regiões da Metrópole - População e Emprego - 2017

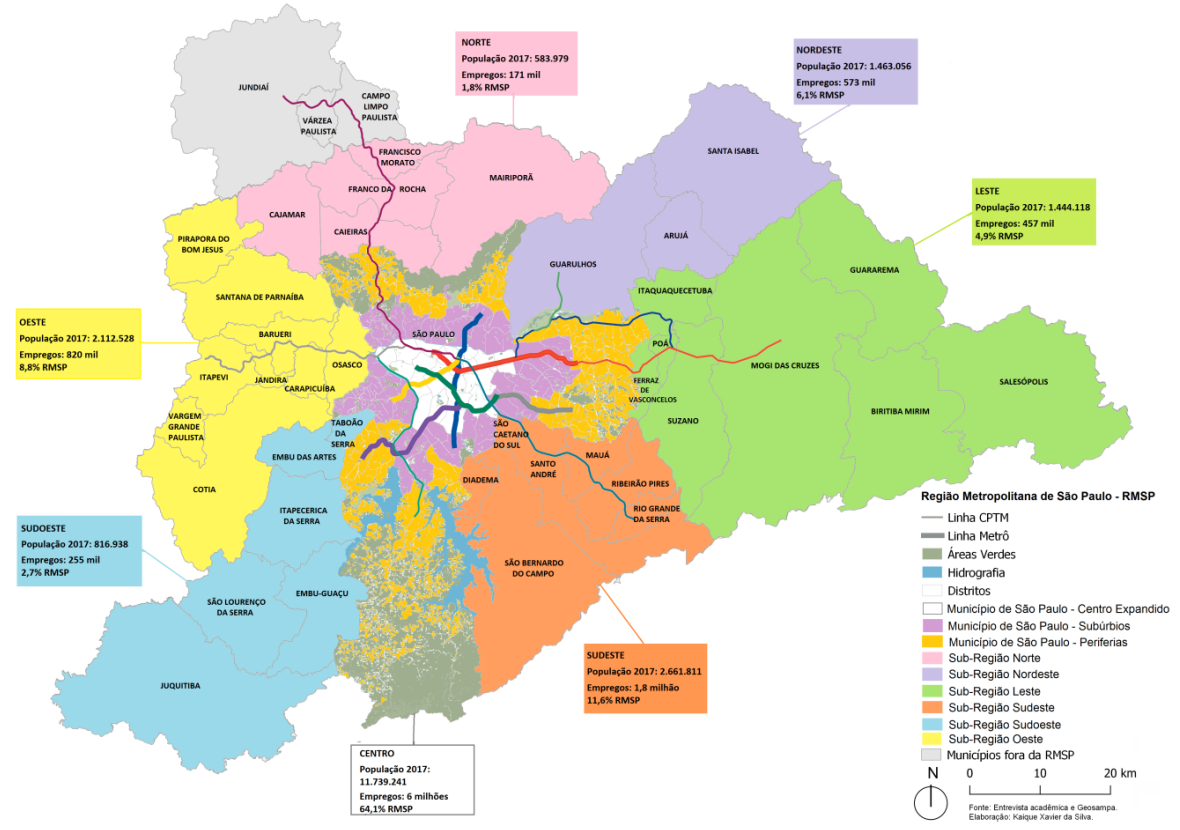

Fonte: Elaboração própria. Metrô-Pesquisa OD 2017

8 Condição socioespacial e (i)mobilidade urbana... 


\section{Figura 2: RMSP - Concentração e Densidade de Emprego - 2017}

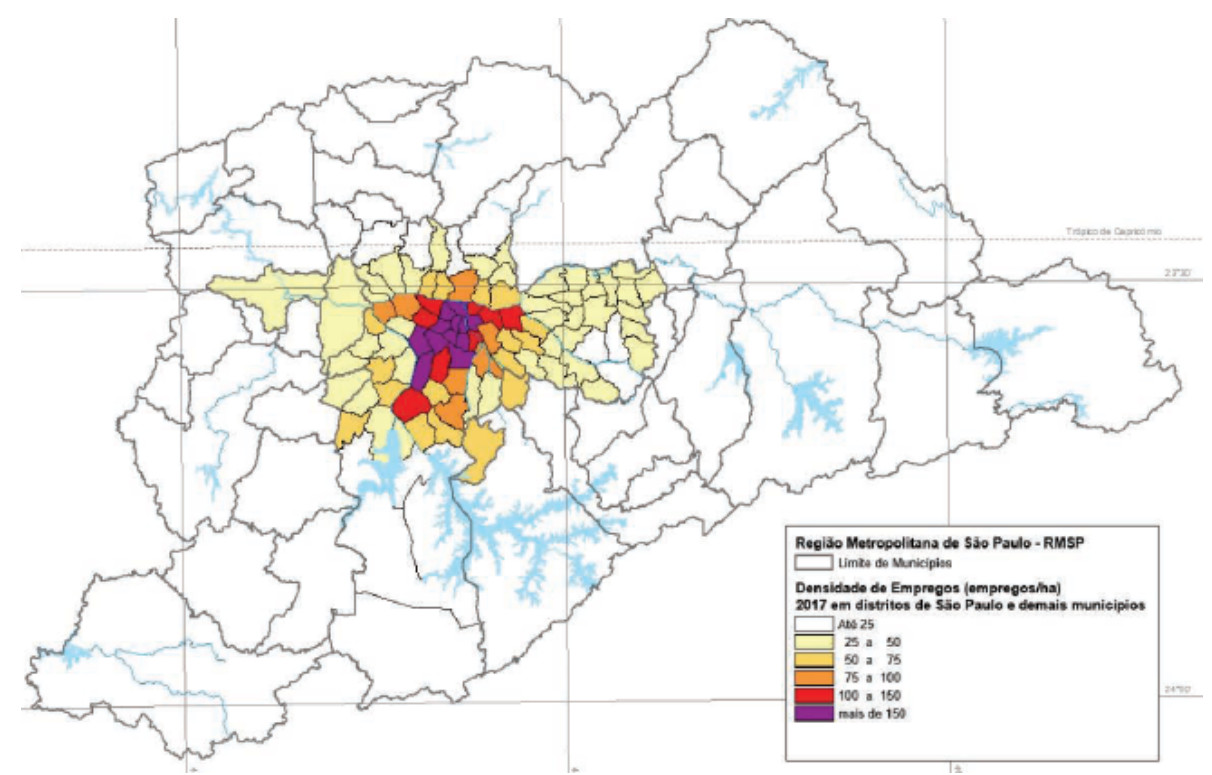

Fonte: Metrô-Pesquisa OD 2017

Percebemos três características da segregação urbana apontadas por Villaça $(2012)^{4}$ nas figuras 1 e 2, mas também a maior concentração de empregos tanto dos mais pobres como dos mais ricos no quadrante sudoeste $^{5}$, que lhe transformou em localização privilegiada do setor terciário (serviço e comércio) e centralidade urbana da economia na metrópole. A desigualdade na distribuição e concentração dos empregos por distritos ou área é um dos fatores responsáveis pelos

4 “1) Com os aspectos políticos: por meio da legislação urbanística, da atuação do Estado, especialmente sobre o sistema de transportes [...]; 2) Com os aspectos econômicos: especialmente por meio do mercado da terra, da formação dos preços da terra e pela atividade imobiliária; 3) Com processos ideológicos, por meio dos quais a classe dominante produz e difunde ideias que visam esconder os processos reais de produção do espaço urbano desigual [...]." (Villaça, 2012: p. 59).

${ }^{5}$ O Quadrante sudoeste de São Paulo, onde se concentra a maior parte da pequenaburguesia, da classe média e da burguesia, vai desde a Avenida Paulista a Santo Amaro, dos Jardins até o Morumbi. 
massivos deslocamentos diários de trabalhadores de suas habitações, nas periferias, aos locais de trabalho nessa localização.

Por isso, a exposição dos resultados desse estudo inicia com abordagem da tríplice segregação socioespacial, étnico-racial e urbana para caracterizar, compreender e explicar as desigualdades sociais a partir da relação periferia-centro e de suas condições de transporte e mobilidade precária. A segregação socioespacial ${ }^{6}$ advém das relações de classes sociais materializadas no espaço produzido de bairro, distrito e cidade, numa escala do lugar, mas como expressão do movimento geral das contradições da circulação do capital e separação entre classes. Diferentes classes podem até ocupar o mesmo território, como é o caso do bairro de Paraisópolis, mas jamais o mesmo espaço que está segregado e separado por classe. A segregação étnico-racial se assemelha a socioespacial e expressa a condição estruturante das relações raciais a partir da segregação residencial, pelo aspecto de que os trabalhadores superexplorados de baixa renda que habitam as periferias estar representado em maioria pela população negra (pretos e pardos) que constitui a classe trabalhadora, como mostram os Mapas da Desigualdade da Rede Nossa São Paulo. E segregação urbana relaciona-se as segregações socioespacial e étnico-racial e se verifica no nível da diferenciação entre áreas da metrópole como expressão do urbano e de um padrão de urbanização desigual. Para explicitar tais diferenças no que designamos por segregação urbana, o município de São Paulo na figura 1 reúne a representação das categorias de periferia, subúrbio e centro expandido com a concentração de determinadas

${ }^{6}$ Há uma longa trajetória no debate sobre segregação socioespacial. Referencio-me nos seguintes autores para sua definição: para Flávio Villaça (1998) a segregação espacial advém de um espaço urbano que é um espaço produzido e consumido por um mesmo e único processo segundo o qual diferentes classes ou camadas sociais tendem a se concentrar cada vez mais em diferentes regiões gerais ou conjuntos de bairros da metrópole. Para Tiarajú D’Andrea (2008), a segregação socioespacial refere-se à separação entre as classes no espaço urbano socialmente produzido. Para Henri Lefebvre $(1991 ; 2000)$, a segregação espacial é resultado do lócus da produção e reprodução das relações sociais de produção, um produto social, mas também de relações sociais, sendo o espaço reproduzível e resultado de repetitivas ações.

10

Condição socioespacial e (i)mobilidade urbana... 
classes nesses territórios, havendo uma concentração maior de trabalhadores de baixa renda em quase todos esses territórios, mas predominantemente nas periferias; de uma classe média e média alta concentrada nos subúrbios; e de uma classe média alta e das classes dominantes do quadrante sudoeste e parte do centro expandido da metrópole.

Nos territórios periféricos espalhados pela metrópole de São Paulo, entendemos que eles se caracterizam pela distância em relação ao centro e pela maior concentração de trabalhadores de baixa renda, habitações autoconstruídas e transporte precário. Todavia, ao longo de décadas houve disputas e mutações na noção de periferia, como analisado por Tiarajú D'Andrea (2020), termo que derivou dos debates econômicos no âmbito do desenvolvimento na Comissão Econômica para América Latina (CEPAL), ocorridos nas décadas de 1950 e 1960, a partir da noção de periferia do capitalismo em relação às economias centrais; nos estudos urbanos que começam a analisar a explosão demográfica nas cidades latino-americanas introduzindo uma predominância acadêmica; e no caso de São Paulo, intelectuais denominaram periferia como território geográfico cujas principais características eram pobreza, precariedade e distância em relação ao centro. Nas décadas de 1970 e 1980 interpretações no campo do marxismo, por um lado, tratam a produção da cidade como reflexo da produção econômica, e por outro, como lócus da produção e reprodução da sociedade, além de um novo olhar lançado por movimentos populares nesses territórios como as pastorais, Clubes de Mães, etc., que tinham como a referência as noções de "povo", "trabalhador" e "classe trabalhadora" e não usavam o termo periferia, utilizado com potência e positividade por grupos e coletivos culturais como os de RAP no final da década de 1980 e ao longo de 1990 (D'Andrea, 2020: p. 20-21).

Então, nos referenciamos na noção de periferia de $\mathrm{D}^{\prime}$ Andrea (2020) como "maneira adequada" de que a classe encontrou para se representar em determinado momento histórico, definição construída 
por meio de relações sociais internas e embates com outras classes a partir da significação de seus habitantes: não apenas como espaço geográfico, mas como expressão de um modo de vida conflituoso e contraditório de como a classe trabalhadora, representada por coletivos e produtores culturais, resignificou o termo para além dos efeitos da violência e da pobreza ao introduzir cultura e potência por meio do compartilhamento de costumes, modos de vida e condições sociais nesses territórios.

Com relação aos outros territórios, a Prefeitura de São Paulo definiu a área do centro expandido que abarca uma área com mais de 190 km², com alto padrão de verticalização e valorização imobiliária, concentração das classes de mais alta renda, empregos e veículos motorizados. Denomina-se como subúrbio a área intermediária entre a área central-sudoeste e a periferia, sendo ele composto por bairros mais antigos e com padrões urbanísticos com maior regulação (D'Andrea, 2020: p. 28).

Subúrbio é um termo que designava bairros distantes do centro e quase sempre caracterizados pelas estações de trem e via férrea, presença de indústrias, proximidade da divisa da cidade com o rural e loteamentos regidos por legislação. Tiarajú D'Andrea (2020) se referenciou na categoria subúrbio dos estudos de José de Souza Martins (1992; 2001), que analisou sua origem no século XVIII e como ele foi definido por moradores sujeitos dessa espacialidade, além de comparações entre subúrbios paulistano e parisiense. Esse resgate foi importante para resignificá-lo no processo de transformação na redefinição urbana recente, ao diferenciar territórios que são vistos por parte da população e estudiosos como sendo parte das periferias, quando na realidade são subúrbios. Para Martins, subúrbio referia-se à atual região do $\mathrm{ABC}$ Paulista, povoado por moradores de fazendas e bairros rurais, ligados à dinâmica cotidiana da cidade de São Paulo, mas em vias de urbanização.

Os processos que produziram essa tríplice segregação do urbano têm como sujeito num polo da relação às classes dominantes, formadas

$\overline{12}$ Condição socioespacial e (i)mobilidade urbana... 
pela burguesia industrial, financeira, comercial e latifundiária que tem o poder de determinar a produção dos sistemas viários e de transportes para atender suas necessidades enquanto classe social; num polo intermediário as classes médias, que são formadas por trabalhadores formais assalariados intelectuais, técnicos e gestores como professores universitários, engenheiros, arquitetos, jornalistas, gerentes de bancos, entre outros, e a pequena burguesia, composta por pequenos proprietários comerciantes, produtivos, etc., que influenciam a opinião pública pela questão do trânsito; e no outro polo, os trabalhadores formais assalariados que realizam trabalhos manuais e recebem baixos e baixíssimos salários, e os trabalhadores informais que precisam "se virar" ante ao alto desemprego e ausência de alternativas de trabalho formal e encarar, muitas vezes, condições precárias de trabalho.

Para condução da pesquisa e posterior análise das experiências vividas no transporte, realizamos entrevistas por meio de grupos focais $^{7}$ com trabalhadoras e trabalhadores de determinadas categorias profissionais de trabalho, com o objetivo de partir de suas condições de vida cotidianas concretas e apreender as contradições, as estratégias e o espaço vivido nesse ir e vir diário do trabalho e sua relação com a periferia e a cidade. Entrevistamos pessoas de categorias de trabalho precário e que empregam trabalhadores com escolaridade média e baixa: 1) diaristas; 2) domésticas; 3 ) auxiliares de limpeza; 4) teleoperadores; 5) pedreiros e ajudantes de pedreiros; e dez questionários para pessoas com ensino superior: 6) professores; 7) pesquisadores; 8) técnicos diversos. Consideramos essas categorias representativas da população periférica que se vira para trabalhar e reproduzir a existência de si e de sua família como condição de vida.

\footnotetext{
7 Realizamos quatro grupos focais no Conjunto José Bonifácio com três mulheres diaristas; na Secretaria da Fazenda do Estado de São Paulo, na Praça da Sé, com onze mulheres auxiliares de limpeza; no canteiro de obras Alexios Jafet, no Jaraguá, da Associação dos Trabalhadores Sem Terra da Zona Oeste, com cinco pessoas (quatro homens e uma mulher); na sede do Sintratel (Sindicato dos Trabalhadores do Telemarketing de São Paulo) na Santa Cecília com cinco homens; e no Jardim Conceição em Osasco com sete mulheres.
} 
Na exposição dessa análise, nos referenciamos nas noções de espaço, cotidiano e urbano para desvendar algumas percepções de trabalhadores(as) que vivenciam o cotidiano do transporte coletivo e do tempo de deslocamento a partir da periferia. Para ampliar a definição de periferia no sentido dado pelo processo de urbanização desigual que impera na sociedade, propomos uma interpretação que considere a condição socioespacial a partir da infraestrutura viária de transporte, do tempo de deslocamento socialmente determinado e do cotidiano da mobilidade perversa vivido por quem reside na periferia como mais uma camada da desigualdade urbana e das condições de vida de seus habitantes.

\section{Transporte e deslocamento: uma condição socioespacial de vida na periferia}

A história da metrópole paulistana foi mediada por uma série de relações que contribuíram para sua forma urbana, estrutura e função na reprodução social. Elas foram intensificadas com a inauguração da ferrovia, em 1867, com a expansão dos subúrbios-estações, e no século $X X$, com o sucateamento das ferrovias e pela opção das classes dominantes pelo rodoviarismo, modelo que contribuiu para a expansão das periferias. Sua urbanização promoveu a produção de espaços diferenciados por classe, étnico-racial e território, além de áreas da metrópole de acordo com a produção e a circulação no regime de acumulação de capital que resultou em segregação urbana conduzida pelas classes dominantes. Em seu desenvolvimento, a urbanização resultou na área habitada por grande parte da classe trabalhadora denominada por periferia e no padrão desigual de assentamentos precários e autoconstruídos, ou planejados pelo Estado como conjuntos habitacionais que proliferaram em territórios distantes do centro urbano da metrópole.

As periferias são resultado de características da vida urbana de reunião, encontro e aglomeração em contradição com segregação,

\begin{tabular}{l|l}
\hline 14 & Condição socioespacial e (i)mobilidade urbana...
\end{tabular} 
separação e dominação por meio do espaço, ao indicar que as relações vividas e percebidas por seus habitantes permitem encontrar o sentido da urbanização e a lógica dessas relações. Nesse sentido, o processo socioespacial de periferização em São Paulo pode ser entendido como elemento de formação da classe trabalhadora periférica que, diferentemente das classes e camadas médias e dominantes que habitam o quadrante sudoeste, vai constituir um modo de vida distinto mediante a condição socioespacial. Essa condição, caracterizada por diferentes condições de vida na metrópole, evidencia que a formação de diferentes classes sociais perpassa os locais de habitação e trabalho e suas diferentes condições de produção e circulação. Diante disso, a apropriação e o fazer-se da classe mostram a importância da experiência vivida no espaço que é resultado de relações na reprodução da existência, da qual entendemos como periférica.

A partir desse momento, ao longo do artigo, e considerando as desigualdades urbanas, apresentamos alguns relatos do estudo de caso de experiências vividas no transporte por trabalhadores(as), que mostram a lógica dessa desigualdade mediante ao que designamos por cotidiano da mobilidade perversa. $\mathrm{O}$ caso de dona Benedita de Oliveira, mãe e avó, mulher negra e periférica, aposentada e trabalhadora diarista é bem característico do problema social que abordaremos aqui, pois em seu relato disse: "na semana, eu trabalho terça no Belém, quarta no Tatuapé e quinta em Moema", o que mostra uma mobilidade variável ao trabalho. Ela mora na Cohab 2 Itaquera e mesmo aposentada precisava trabalhar para complementar a renda, por receber um salário mínimo de aposentadoria não suficiente para as necessidades de sua família. Ela se aposentou em uma creche onde trabalhou na cozinha, e foi trabalhar como diarista por ser um trabalho flexível, porém, precário e sem direitos, mas com tempo para realizar outras necessidades e não ficar prisioneira de jornadas de trabalho rígidas. Sua filha, Márcia de Oliveira, relatou: 
Eu trabalhei em fábrica, quando eu casei cuidava de criança, vendi pano de prato, fazia faxina, já fiz de tudo nessa vida. [...] Quando eu era jovem, eu morava na Vila Formosa e eu sempre trabalhei perto de casa. Comecei na fábrica com quinze anos, perto de casa. Eu já trabalhava antes, com nove anos, em casa de família. (Márcia de Oliveira, grupo focal, 2018).

Marcia durante a entrevista era diarista e realizava trabalhos domésticos de limpeza há oito anos no Parque São Domingos e cinco anos na Lapa na Zona Oeste, e vivia há 20 anos no distrito de José Bonifácio na periferia leste. Atravessava a cidade três vezes por semana e utilizava transporte coletivo num percurso de duas horas e quarentas minutos de ida e volta. A Márcia é negra, mãe sozinha de duas filhas e avó, pelas quais trabalhava para ajudá-las nos estudos e reprodução de suas vidas. Márcia é o tipo de mulher trabalhadora que está na base da pirâmide social: mulher, negra, pobre. Três determinações interrelacionais articulam sua condição de vida: gênero, raça e classe, ao estar numa condição socioespacial distinta de suas patroas brancas e de classe média.

Ângela Davis (2016: p. 17) mostrou a inter-relação entre questões de gênero, raça e classe ao abordar a condição da mulher negra nos Estados Unidos, ao dizer que as mulheres negras sempre trabalharam mais fora de casa do que suas irmãs brancas, ao reproduzir um padrão estabelecido durante o inicio da escravidão e, na condição de escravas, eram trabalhadoras domésticas - cozinheiras, arrumadeiras ou mammy na casa-grande. Davis mostra como as relações de classes são mediadas por relações de gênero e étnico-raciais e são estruturais, ao evidenciar que a condição da mulher negra precisa ser base de qualquer análise para transformar radical a sociedade, em decorrência do "legado da escravidão", que está relacionada aos trabalhos de reprodução: doméstico, cuidadora, limpeza. Antes de Davis, Lélia Gonzalez (2020) analisou como o racismo estrutural à brasileira impede uma consciência objetiva e exerce violência simbólica sobre a mulher

$\overline{16}$ Condição socioespacial e (i)mobilidade urbana... 
negra (racismo e sexismo) em decorrência da miscigenação e do mito da democracia racial.

Não por acaso que Márcia de Oliveira, filha de Benedita, reproduziu a condição de vida da mãe inclusive nessas atividades de trabalho. Isso não quer dizer que não haja mulheres negras ocupando outras posições no processo de produção e reprodução, mas as que ocupam tais posições de trabalhos reprodutivos se mostram como confirmação de uma "regra" que também é um "legado da escravidão" no Brasil. Márcia relatou ainda seu cotidiano de deslocamentos e horários para chegar ao trabalho:

Eu trabalho numa casa três vezes na semana: segunda, quarta e sexta. Eu saio daqui cinco horas da manhã, pego o trem, desço na Luz. Na Luz pego o Morato (trem sentido a Estação Francisco Morato) e desço na Lapa. Na Lapa eu espero o ônibus e desço na Anhanguera (rodovia), ali no Parque São Domingos. [...] Mas eu acho rápido, porque eu saio daqui cinco horas, pego o trem cinco e 10 minutos, cinco e pouco, e quando dá seis horas e vinte minutos eu já estou lá. Quinze para as seis eu estou na Lapa. Aí eu espero o ônibus que passa seis horas e cinco minutos. Ou se não eu pego qualquer ônibus, desço na Anhanguera e vou a pé. Eu gosto de andar. (Márcia de Oliveira, grupo focal, 2018).

A rapidez relatada por Márcia relacionava-se ao fato dela morar perto da Estação José Bonifácio da $\mathrm{CPTM}^{8}$, o que lhe permitia chegar ao centro em cerca de 30 minutos, algo que antes da inauguração era de 1 hora e 30 minutos. O transporte metroferroviário permite maior acessibilidade e rapidez, mas não resolve em si o problema da mobilidade urbana, pois ela está determinada pela segregação urbana entre locais de moradia e emprego de parte da classe trabalhadora periférica. Outro aspecto era que Márcia tinha que sair de casa às 5

${ }^{8}$ Companhia Paulista de Trens Metropolitanos. Estação inaugurada em 2000. 
horas da madrugada para chegar 6 horas e 20 minutos no emprego e trabalhava até as 16 horas. Esse tipo de trabalho de reprodução relacionava-se as tarefas de limpeza e preparação do café da manhã para patroas, patrões e suas famílias.

Outro caso semelhante foi o das trabalhadoras da limpeza na empresa Top Service que reunia 88 funcionárias entre encarregadas e auxiliares de limpeza que chegavam às 6 horas da manhã no trabalho, antes que os demais trabalhadores. Das onze mulheres entrevistadas na empresa de limpeza, oito eram negras e moradoras da periferia de São Paulo e representam a maioria das trabalhadoras de limpeza como resultado de um processo social, histórico e desigual que pesa mais sobre as mulheres negras trabalhadoras.

O caso da Ismênia dos Santos, moradora do distrito do Itaim Paulista, periferia leste, que trabalhava pela empresa de limpeza na Praça da Sé, mostra isso: "Para vir é mais rápido porque não tem trânsito, né? Então demoro 1 hora, 1 hora e 20 minutos. Mas para ir é um carma, o negócio é feio. [...] Porque eu demoro quase 3 horas para ir embora". Para ir e voltar do trabalho a Ismênia utilizava ônibus do Jardim Camargo Velho, onde morava há 14 anos, e atravessa a Zona Leste para chegar até a Praça da Sé. Na volta, fazia o mesmo trajeto em mais tempo. No relato de Adriana dos Santos, ficou explicita essa condição:

Porque na madrugada Sandro é tranquilo na vinda. Mas na volta, horário de pico, se gasta duas e meia ou três horas. [...] Geralmente cinco e meia a gente já está por aqui. Quer dizer, voce pega um ônibus dez para as quatro da manhã, voce consegue chegar aqui em uma hora. À tarde não, você demora mais. O mais rápido é uma hora e meia. (Adriana dos Santos, grupo focal, 2018).

As experiências relatadas mostram as dificuldades de deslocamentos que remetem a organização do sistema de transporte na metrópole paulistana, caracterizado a seguir. O tipo de transporte

\begin{tabular}{l|l}
\hline 18 & Condição socioespacial e (i)mobilidade urbana...
\end{tabular} 
(ônibus, micro-ônibus, trem e metrô) e a infraestrutura urbana remete a condição socioespacial que está dada pelos sistemas viários de transportes produzidos socialmente, mas não revela em si os processos ocultos dessa condição que tem relação direta com a tríplice segregação socioespacial, étnico-racial e urbana na metrópole.

No município de São Paulo havia, em 2018, cerca de 14.500 ônibus e micro-ônibus que operavam em 50 Linhas Estruturais e 101 Linhas Locais, por meio de 32 empresas privadas concessionadas ${ }^{9}$ geridas pela SPTrans. O Metrô ${ }^{10}$ de São Paulo, que junto a CPTM ${ }^{11}$ constituem o sistema metroferroviário da metrópole, transportaram em média, 3,7 milhões de passageiros por dia em $2018^{12}$. A rede metroviária possuía seis linhas com 89 estações e chegou, em 2020, a 103,8 quilômetros, incluindo 11,6 quilômetros da Linha 15 Prata - Monotrilho. Quatro linhas são operadas pelo Metrô e duas pela empresa privada CCR, todas elas somente na cidade de São Paulo. Por sua vez, a CPTM era responsável pela operação de sete linhas, num total de 273 quilômetros de ferrovia e 94 estações e atendia a 22 municípios, sendo 19 deles na metrópole paulista, transportando 2,8 milhões de passageiros por dia. Desde sua criação, a CPTM atende os subcentros nas periferias e subúrbios e promove a ligação com o centro da metrópole. Por fim, a EMTU ${ }^{13}$ fazia a gestão e fiscalização do sistema metropolitano em um universo de 43 empresas concessionadas, de 547 linhas e uma frota 4.355 ônibus. Não computamos a frota de ônibus dos demais 38 municípios da RMSP.

\footnotetext{
${ }^{9}$ Fonte: SPTrans, criada em 1995 e faz a gestão e fiscalização do transporte coletivo por ônibus.

10 A Companhia do Metropolitano de São Paulo foi fundada em 1968 e entrou em operação em 1974.

${ }^{11}$ A CPTM foi criada em 1992, após fusão de outras companhias.

12 Metrô de SP. Indicadores de Demanda, Fevereiro de 2019.

${ }^{13}$ Empresa Metropolitana de Transportes Urbanos.
} 
Diante dessa condição, um dos problemas fundamentais em São Paulo relaciona-se ao transporte cotidiano de trabalhadores, que podemos ver no mapa e na análise a seguir.

\section{Figura 3: Sistema do Transporte Metropolitano de São Paulo - 2020}

\section{Mapa do Transporte Metropolitano}

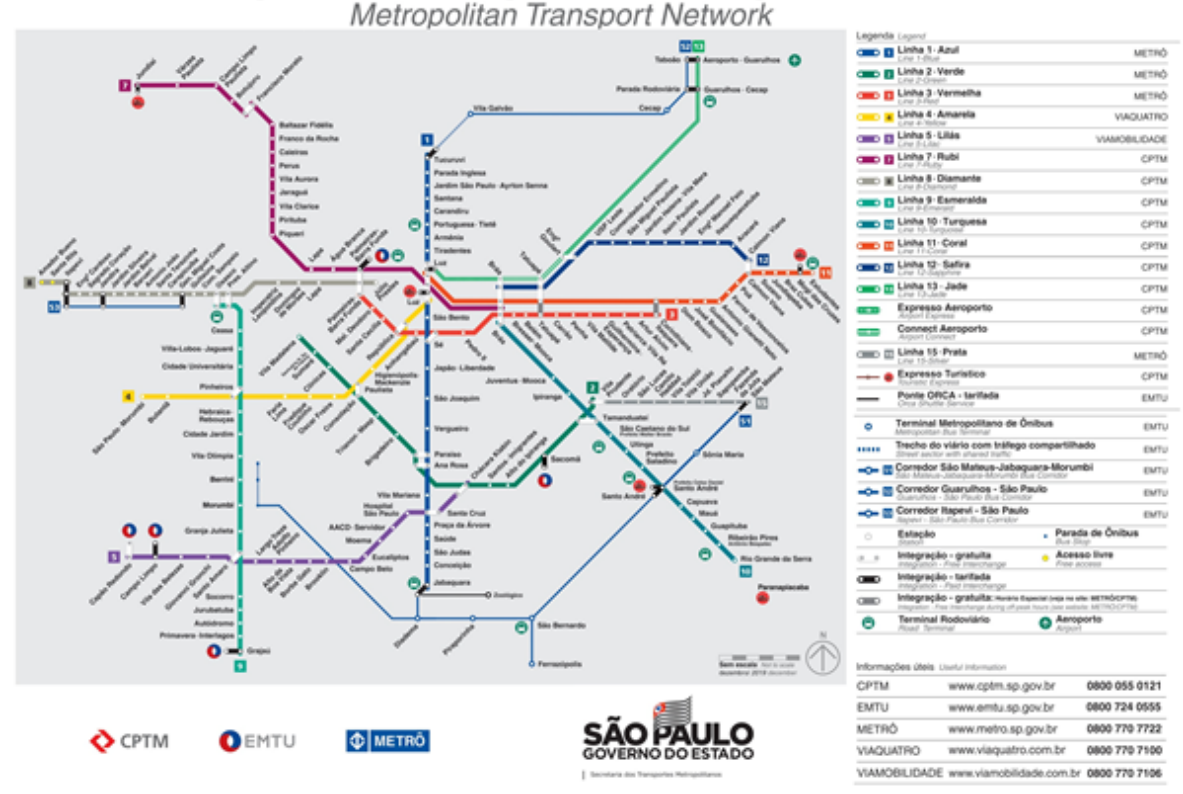

Fonte: Secretaria dos Transportes Metropolitanos do Governo do Estado de São Paulo.

Há entendimento entre estudiosos do urbano que o desenvolvimento do capitalismo exige um sistema de transportes de massa com referência a mobilidade urbana e rapidez dos habitantes. Porém, as contradições do capitalismo periférico têm-se mostrado avessas a tais premissas técnica sob a realidade de intensa segregação socioespacial, longos e precários deslocamentos, densidade e concentração urbana da força de trabalho nas periferias. Com o crescimento populacional, resultado da aglomeração promovida pela concentração do capital 
em São Paulo e diante da imensidão de sua RMSP composta por 39 munícipios, ocorreu uma expansão da segregação urbana que nos separa. $\mathrm{O}$ crescimento vertiginoso da metrópole com a industrialização pesada na década de 1950 e a urbanização rodoviarista originada do tripé industrial automotivo, petrolífero e construção civil evidenciou que tal urbanização é produto-produtor da expansão capitalista baseada na relação produção-circulação e de desigualdades sociais, urbanas e espaciais.

\section{Tabela 1: Dados Globais RMSP: Evolução População, Viagens e Frotas de Veículos}

\begin{tabular}{|l|r|r|r|r|r|r|}
\hline VARIÁ VEIS & $\mathbf{1 9 6 7}$ & $\mathbf{1 9 7 7}$ & $\mathbf{1 9 8 7}$ & $\mathbf{1 9 9 7}$ & $\mathbf{2 0 0 7}$ & $\mathbf{2 0 1 7}$ \\
\hline População (milhares de habitantes) & 7.097 & 10.276 & 14.248 & 16.792 & 19.535 & 20.822 \\
\hline Total de Viagens (milhares/dia) & - & 21.304 & 29.400 & 31.432 & 38.094 & 42.007 \\
\hline $\begin{array}{l}\text { Viagens Motorizadas (milhares/ } \\
\text { dia) }\end{array}$ & 7.187 & 15.263 & 18.642 & 20.458 & 25.167 & 28.280 \\
\hline Frota de Autos (milhares) & 493 & 1.392 & 2.014 & 3.092 & 3.601 & 4.223 \\
\hline Índice de Mobilidade Total (*) & - & 2,07 & 2,06 & 1,87 & 1,95 & 2,02 \\
\hline $\begin{array}{l}\text { Índice de Mobilidade } \\
\text { Motorizada (**) }\end{array}$ & 1,01 & 1,49 & 1,31 & 1,22 & 1,29 & 1,36 \\
\hline Taxa de Motorização (***) & 70 & 135 & 141 & 184 & 184 & 212 \\
\hline Empregos (milhares) & - & 3.758 & 5.647 & 6.959 & 9.066 & 9.367 \\
\hline Matrículas Escolares (milhares) & 1.088 & 2.506 & 3.676 & 5.011 & 5.251 & 5.487 \\
\hline
\end{tabular}

Fonte: Metrô-Pesquisas OD 1967/1977/1987/1997/2007/2017

* Índice de Mobilidade Total: Número de viagens totais por habitante

** Índice de Mobilidade Motorizada: Número de viagens motorizadas por habitante *** Taxa de Motorização: Número de automóveis particulares por 1.000 habitantes

Na tabela 1 vemos o crescimento da população da RMSP desde 1967 até 2017. Em termos históricos representa um curto período. De 7,09 milhões em 1967, a população cresceu para 20,8 milhões em 2017, e essa imensa aglomeração não pode ser vista com naturalidade. O processo de urbanização representa concentração, expansão e configuração de forças produtivas sociais desenvolvidas a partir das 
relações de produção por meio da aglomeração urbana que, no caso desse estudo, se verifica no desenvolvimento dos sistemas viários de transporte para a produção dessa quantidade de 42 milhões de viagens diárias indicada pela OD, mas com diversas desigualdades.

A evolução e a composição das viagens diárias por modo permitem observar a distribuição nesse montante de 42 milhões de viagens/dia:

\section{Figura 4: Distribuição Modal das Viagens \\ Internas - Metrópole de São Paulo - 2017}

\section{COMPOSIÇÃO DAS VIAGENS}

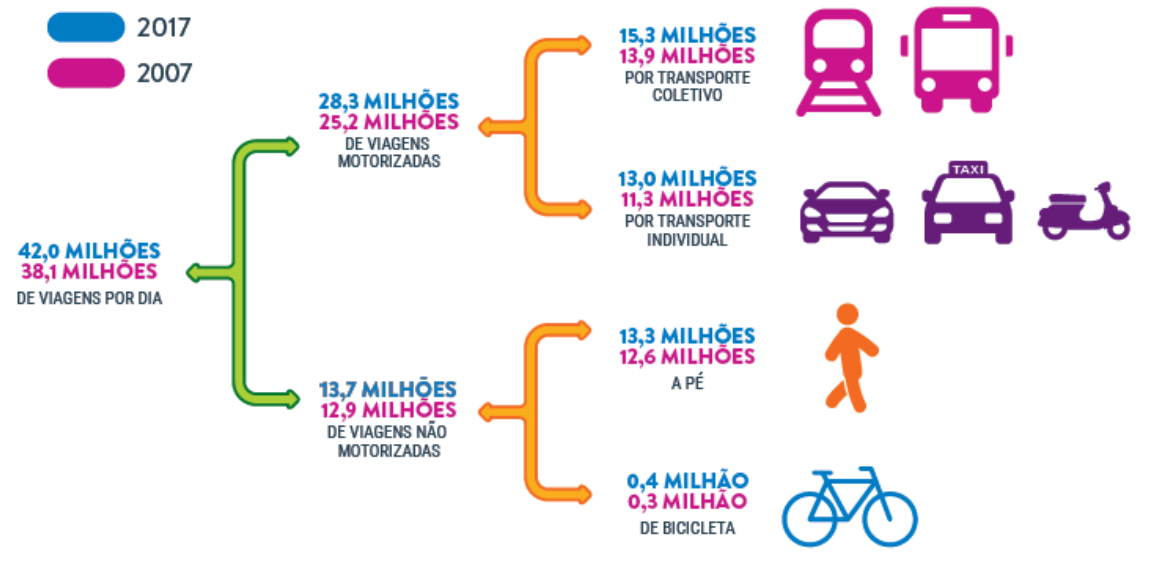

Fonte: Metrô-Pesquisa OD 2017

A distribuição modal evidencia que o transporte coletivo (ônibus, metrô e trem) foi o mais utilizado pela população trabalhadora com 15,3 milhões de viagens diárias, e preponderou em 2017 em relação ao transporte individual (automóvel, taxi, motocicleta) com 13,0 milhões e ao modo a pé com 13,3 milhões. O transporte coletivo mais utilizado foi o ônibus com 8,6 milhões de viagens diárias, ao evidenciar o predomínio da urbanização rodoviarista se relacionarmos ao transporte 
individual. A disputa entre transporte coletivo e transporte individual fica patente no gráfico a seguir:

\section{Figura 5: Divisão Modal das Viagens Motorizadas - RMSP 1967 a 2017}

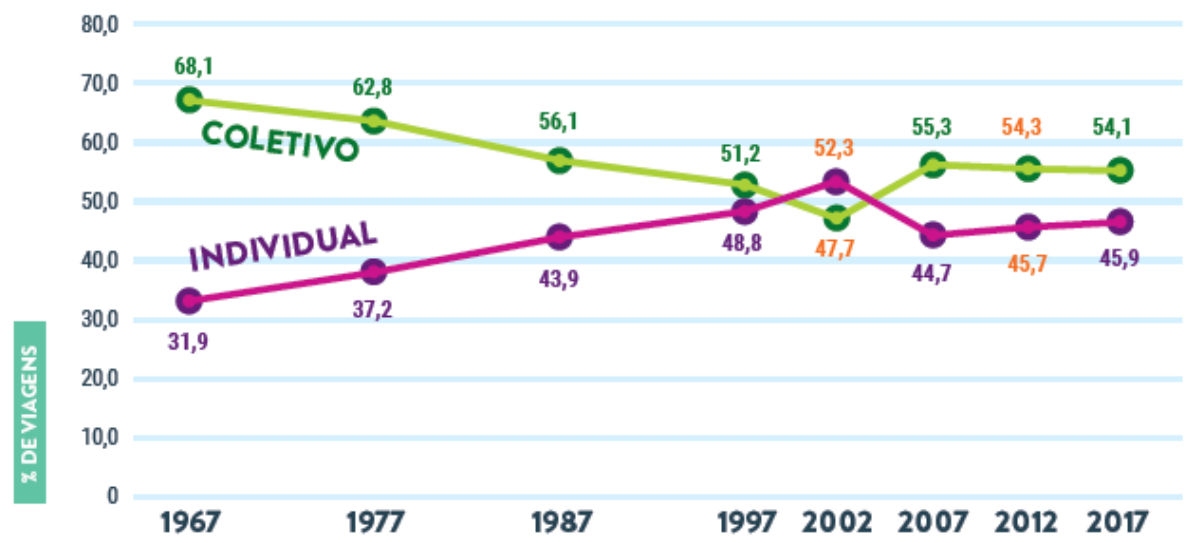

Fonte: Metrô-Pesquisa OD 2017

Em 1968 essa medição foi iniciada pela OD do Metrô, e o gráfico mostra a disputa entre os modos coletivo e individual, pois quando o individual subiu, o coletivo caiu, o que evidencia uma relação direta com os investimentos públicos do Estado em priorizar um ou outro modo. Em 2002 pela primeira vez o individual ultrapassou o coletivo, que retomou crescimento em 2007, com a retomada de investimentos do Governo do Estado de São Paulo (GOVESP) na expansão do Metrô e da CPTM.

O crescimento do transporte individual resultou do longo processo de sucateamento das ferrovias, aposentadoria dos bondes e precarização do transporte coletivo que perdeu espaço para o transporte individual, resultado da urbanização rodoviarista e dependência econômica, opção das elites pela inserção subordinada ao capitalismo internacional. Esse crescimento relacionou-se às crises e impasses do capitalismo que facilitou a acumulação do capital e abriu novos 
caminhos para a valorização desenfreada, encontrando na produção capitalista do espaço, analisada por David Harvey (2006; 2014), o estágio superior de acumulação, que requer organização geográfica especifica para realização desses ciclos. Todavia, os sistemas de transportes desenvolvidos socialmente e distribuídos desigualmente pelos territórios metropolitanos fortalece tríplice segregação do urbano.

A desigualdade na distribuição de empregos privados e públicos, equipamentos como escolas, hospitais, creches, cultura, etc., e transporte, indicam um problema profundo nessa urbe. Para apreender essa problemática é importante entender que trabalhadores habitantes da periferia de São Paulo e RMSP vivem uma condição socioespacial diferente de outras classes sociais que se caracteriza pelos seguintes aspectos:

a. Distância das habitações nas periferias em relação aos centros geográfico da cidade e da metrópole onde se concentram empregos, educação, serviços e lazer (urbano);

b. Tempo de deslocamento no cotidiano da mobilidade perversa (espaço);

c. Espaço percebido no transporte (solidariedade, conflitos, precariedade) (cotidiano).

O transporte tornou-se meio de acumulação e espoliação urbana de empresas privadas: o custo tem sido maior ao trabalhador que necessita do transporte. Em tempos de cidades globais como miragem do desenvolvimento, observamos na metrópole paulistana o global com entraves locais mediados pela tríplice segregação. Por isso, as linhas de ônibus estão organizadas para levar os trabalhadores aos postos de trabalho e seguem a lógica radial-concêntrica com poucas linhas que fazem o trajeto entre os bairros. Portanto, os sistemas viários de transportes são responsáveis também pela produção da segregação urbana existente na metrópole, mediante os deslocamentos entre localizações produzidas socialmente e segregadas pelas relações de classes reproduzidas espacialmente, ao reforçar espaços diferenciados e a condição socioespacial da classe trabalhadora periférica.

24 Condição socioespacial e (i)mobilidade urbana... 


\section{Espaços vividos e percebidos: tempo-espaço e cotidiano da mobilidade perversa}

Os espaços vividos e percebidos ${ }^{14}$ por trabalhadores periféricos mostram uma lógica oriunda das necessidades e estratégias de reprodução e deslocamentos que se contrapõem a lógica do espaço concebido por planejadores de transporte e do urbano, que pensam a circulação de modo abstrato e quantitativo sem às vezes considerar a qualidade e as múltiplas necessidades dos indivíduos nesses deslocamentos. As condições desses deslocamentos resultam de determinações econômicas (mercados de terra, trabalho e transporte), políticas (legislação urbanística e planejamento de transporte) e ideológicas (ocultação da lógica de acumulação e divisão das classes) já apontadas por Villaça (2012).

As condições de deslocamento, como parte da condição socioespacial, relacionam-se diretamente à segregação urbana e se entrelaçam a tríade trabalho, moradia e mobilidade precária de parte da classe trabalhadora. Como a maioria dos trabalhadores dispendem mais de uma hora nos deslocamentos, as experiências vividas no transporte são diversas e importantes para o entendimento do que é viver na periferia. Retomando os relatos, o caso de Natalina da Silva, que morava na Cohab 2 Itaquera e trabalhava no Jabaquara, subúrbio sul, e no município de São Bernardo do Campo, mostra tais experiências:

Outro dia eu peguei esse trem aqui e tinha uma jovem grávida dentro. Chegou a hora do parto dela. No trem. Ela começou a passar mal, passar mal mesmo, sabe, aí pegaram e tocaram

\footnotetext{
${ }^{14}$ Para Henri Lefebvre (2000) a tríade espaço percebido (l'espace perçu) como prática espacial que se descobre o espaço percebido decifrando-o na realidade cotidiana; espaço vivido (l'espace vécu) se refere ao espaço das representações, dos habitantes e usadores que se apropriar do espaço pelas imagens e símbolos que acompanham; e espaço concebido (l'espace conçu), diz respeito às representações do espaço por acadêmicos, cientistas, planejadores, urbanistas e tecnocratas.
} 
aquele negócio pro trem parar, mas o trem não pára, né, só vai parar na próxima. [...] Aí fizeram uma roda lá, eu estava vindo para cá e não deu para ver. Fizeram uma roda lá, e a mulher lá tendo dor no chão lá, um monte de gente. [...] Teve o bebê lá. Nasceu! Aí quando desceu, desceu lá no Tatuapé. [...] Aí eu cheguei na minha irmã toda feliz. Contei para minha irmã que disse: "nossa, que coisa legal". Falei "coitada da mulher, ficou toda constrangida". (Natalina da Silva, grupo focal, 2018).

Natalina da Silva relatou um acontecimento bonito que decorreu de uma jovem mãe dar à luz ao seu filho, mas também um problema a partir da condição socioespacial, porque ela estava sozinha, provavelmente ido ao hospital quando sua bolsa estourou, além do constrangimento que sentiu em viver isso em um espaço público. Como muitas mulheres periféricas moram distantes de hospitais-maternidade que estão desigualmente distribuídos no território urbano, precisam se deslocar de transporte coletivo para chegar ao seu destino. Como as distâncias são longas, ainda que o trem permita diminuir o tempo de deslocamento se comparado ao ônibus, isso não impediu a jovem grávida de entrar em trabalho de parto em pleno transporte.

Esse tempo de deslocamento acima da média para acessar equipamentos de saúde, emprego, educação e outros, se contrapõe ao que é recomendado por especialistas de que a mobilidade cotidiana precisa ser no máximo de quarenta e cinco minutos. O que vemos é o avesso: o cotidiano da mobilidade perversa, que incide sobre corpos, mentes e corações dessas trabalhadoras manuais e domésticas que se deslocam entre uma e duas horas só para ir ao trabalho, e depois para voltar às vezes levam mais tempo devido ao horário de pico. O tempo de deslocamento tornou-se extensão da jornada de trabalho e não permite que essas mulheres façam outras atividades. Ao chegarem à moradia, elas são tomadas pela reprodução de si e da família como uma condição de reprodução social.

\begin{tabular}{l|l}
\hline 26 & Condição socioespacial e (i)mobilidade urbana...
\end{tabular} 
As experiências de deslocamentos de trabalhadores(as) mostram como há uma condição socioespacial de reprodução que constitui a formação da classe trabalhadora e seu modo de vida na periferia. A condição espacial de morar longe do trabalho em determinada localização desprovida de rede ampla de transportes expressa a condição de quem vive nas periferias onde deveria haver mais estações de metrô e outros modais, já que mediante a inauguração da expansão da Linha 15 Prata do Metrô até Jardim Colonial a periferia adquiriu mais 6 estações em 2019-21, totalizando 11 estações em um universo de 90 estações. Isso determina o tempo de deslocamento para quem vive nas periferias. Os relatos de entrevistados sobre dificuldades e situações no transporte mostram tal condição:

Sofria muito mais quando morava na região Leste e dependia da Linha 12- Safira da CPTM. Hoje moro na região sul e estou do lado da Linha 2-Verde do Metrô, com fácil acesso a CPTM da linha Brás - Rio Grande da Serra, e também ao terminal de ônibus e o Fura-Fila (Allan Cunha, questionário, 2019).

Todas as dificuldades! A questão é que, pessoalmente, a pior parte do meu dia é a minha locomoção. Eu não consigo fazer nada sem me locomover pelo menos 1 hora e usar um ônibus e um metrô. Eu posso listar alguma das coisas que mais me deixam exausta: 1) superlotação: eu moro no extremo leste e sou dependente da linha Coral da CPTM e da linha Vermelha do Metrô, uma das linhas mais lotadas da cidade. Não importa o horário do dia, é sempre cheio e desconfortável. Quando eu saio mais cedo, antes das $8 \mathrm{~h}$, é o pior horário. Muitas vezes não dá pra entrar, e quando da pra atender, é de faltar o ar. Não é exagero. Você realmente fica espremido. [...]; 2) falhas e anormalidade: muitas vezes existem problemas de funcionamento. Em pleno horário de pico, o trem para, desliga o ar condicionado, fica um calor insuportável, não especificam qual o problema e nunca 
existe uma previsão de funcionamento; 3) funcionamento limitado: reformas e obras inconclusivas, infinitas. Aos finais de semana, o que deveria ser um momento de lazer se torna uma exaustão, os trens podem ter um funcionamento diferenciado: estações fechadas, vias reduzidas, maior tempo de parada (Gabriela Nogueira, questionário, 2019).

Se transporte público fosse bom, ninguém andava de carro. Aqui não é bom. Transporte público de São Paulo e do Brasil de maneira geral não é bom. Por isso que uma pessoa que compra um carro e anda sozinha, por mais que ela esteja pagando caro na gasolina, mas ela está sentada ali no conforto do carro dela, escutando a música dela e indo pra casa dela. Sem poder ser encoxada, sem poder ter confusão dentro do vagão ou por banco, sem ter alguém gritando e vendendo coisa. (José Pires, grupo focal, 2018).

As dificuldades e situações são diversas, mas podem ser agrupadas em certas categorias, como: localização, lotação, distância, tempo de deslocamento, funcionamento do transporte e conflitos para embarcar. Os depoimentos evidenciam as dificuldades de trabalhadores/as da periferia no uso do transporte coletivo, sempre lotado, com problemas técnicos e desconfortáveis. Destacamos dois aspectos levantados por José Pires: o crescimento de trabalhadores de baixa renda da periferia que adquiriram automóveis e a precariedade da infraestrutura nos extremos da cidade no que tange ao transporte coletivo.

Com efeito, a importância das experiências relatadas toma outra dimensão quando inter-relacionadas a análise dos dados da Pesquisa OD, espacializados em nossa pesquisa para evidenciar o deslocamento pendular casa-trabalho. $\mathrm{O}$ mapa a seguir mostra o fluxo: 


\section{Figura 6: Deslocamentos Externos por Modo}

Coletivo - Periferia Sul - 2017

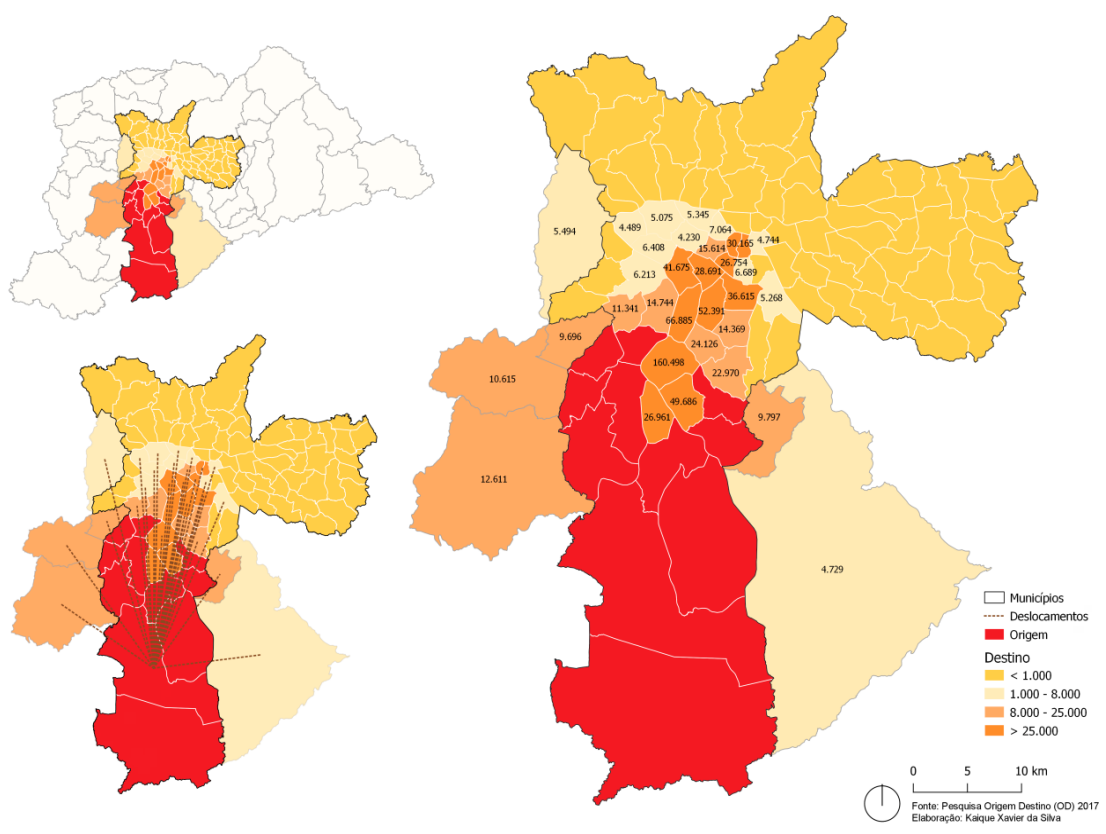

Fonte: Elaboração própria: Mapa Kaique Xavier, dados agrupados OD 2017 Sandro Oliveira.

A figura 6 mostra o fluxo massivo de deslocamentos externos de transporte coletivo da periferia sul para distritos do quadrante sudoeste. Para quem se desloca a partir desse território está em meio as 799 mil viagens externas diárias ${ }^{15}$ por modo coletivo, ao evidenciar que tais deslocamentos expressam o cotidiano da mobilidade perversa. Os deslocamentos iam para localizações no subúrbio sul e centro expandido como Santo Amaro (160.498), Itaim Bibi (66.885), Moema

${ }^{15} \mathrm{O}$ número de viagens internas por modo coletivo da periferia sul foi de $802 \mathrm{mil}$ que somadas às externas totalizava 1,6 milhões. As 1,6 milhões de viagens por modo coletivo somadas as 866 mil por modo individual totalizava 2,4 milhões de viagens diárias. O modo coletivo na periferia sul representa o dobro do modo individual. 
(52.391), Campo Grande (49.686), Pinheiros (41.675), Vila Mariana (36.615) e Centro (30.165). O teleoperador José Pires era parte dos 147 mil deslocamentos externos diários dos que habitam o Jardim Ângela e precisavam se deslocar para trabalho, estudo e/ou outra atividade ao centro expandido.

A periferia sul, cantada em ritmo da poesia pelos Racionais MC's que nomeou as quebradas e tratou com respeito "cada lugar, um lugar, cada lugar, uma lei", é um território em que as dificuldades de habitar e se deslocar são grandes e vividas na pele no cotidiano da população. A figura a seguir mostra a distribuição das faixas de renda por residência para demonstrar as diferenças entre as classes sociais nesses territórios:

Figura 7: Faixa de Renda Familiar por Zona de Residência - Periferia Sul - 2017

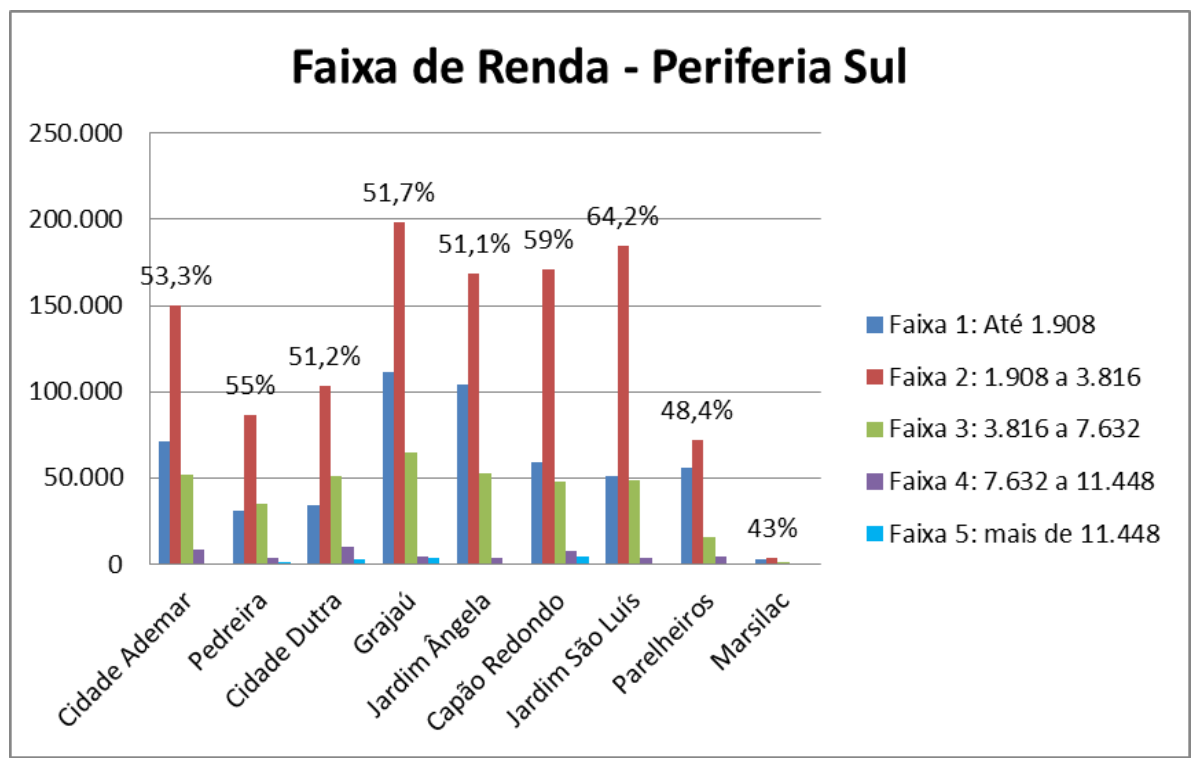

Fonte: Elaboração própria. Metrô-Pesquisa OD 2017

30 Condição socioespacial e (i)mobilidade urbana... 
$\mathrm{Na}$ periferia sul as faixas 1 e 2 representam baixíssima e baixa renda que somadas totalizam 1,6 milhão de habitantes que viviam com até 4 salários mínimos ${ }^{16}$, representando cerca de $79,5 \%$ da população. Esse dado mostra como a periferia é o lugar de trabalhadores de baixa renda explorados no trabalho e espoliados nas condições de moradia e transporte. Destaque para Parelheiros que sobe a 85,9\%, Jardim Ângela 82,7\%, Jardim São Luís 81,8\%, Grajaú 80,8\%, e Capão Redondo 79,5\%.

$\mathrm{Na}$ periferia leste onde o sol nasce e a esperança floresce há semelhanças com a periferia sul. Foram 788 mil $^{17}$ deslocamentos externos por modo coletivo da periferia leste para localizações de empregos no centro expandido, subúrbio leste e quadrante sudoeste. Nesse território registramos no mapa a seguir trinta principais deslocamentos para: Tatuapé (72.166), Centro (69.737), Penha (32.499), Brás (30.851), Mooca (27.026), Belém (24.407), Vila Mariana (23.723), Município de Santo André (20.986) e Município de Guarulhos (17.308). E na Figura 9 as faixas de renda, sendo que as faixas 1 e 2 somadas totalizam 1,8 milhão de habitantes com até 4 salários mínimos, o que representava $78,5 \%$ da população, ao evidenciar alta concentração de baixa renda. Em relação aos distritos no gráfico, Lajeado sobe a média para 89,3\% nessas faixas; São Rafael 87,5\%; Itaim Paulista 86,3\%; José Bonifácio 81,3\%; Cidade Tiradentes 80,3\%; e Itaquera cai para 74,5\%; Guaianases 73\%; Jardim Helena 73\%; Iguatemi 73\%; e São Mateus $63,6 \%$.

\footnotetext{
${ }^{16}$ A referência do salário mínimo é do ano de 2018.

17 Periferia leste: viagens internas modo coletivo foi 797 mil, somada às externas totalizava 1,5 milhões, que somadas as 1,01 milhão do modo individual totalizava 2,5 milhões de viagens diárias.
} 
Figura 8: Deslocamentos Externos por Modo

Coletivo - Periferia Leste - 2017

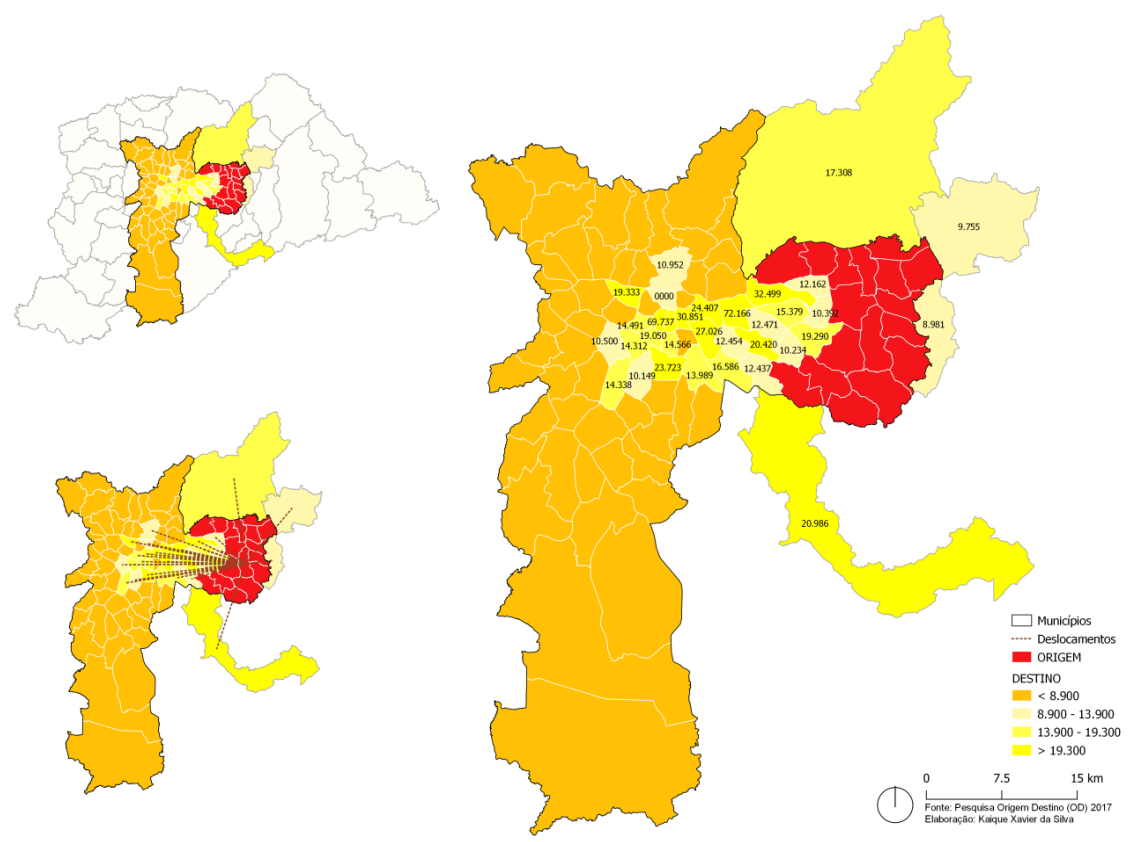

Fonte: Elaboração própria: Mapa Kaique Xavier, dados agrupados OD 2017 Sandro Oliveira. 


\section{Figura 9: Faixa de Renda Familiar por Zona de Residência - Periferia Leste - 2017}

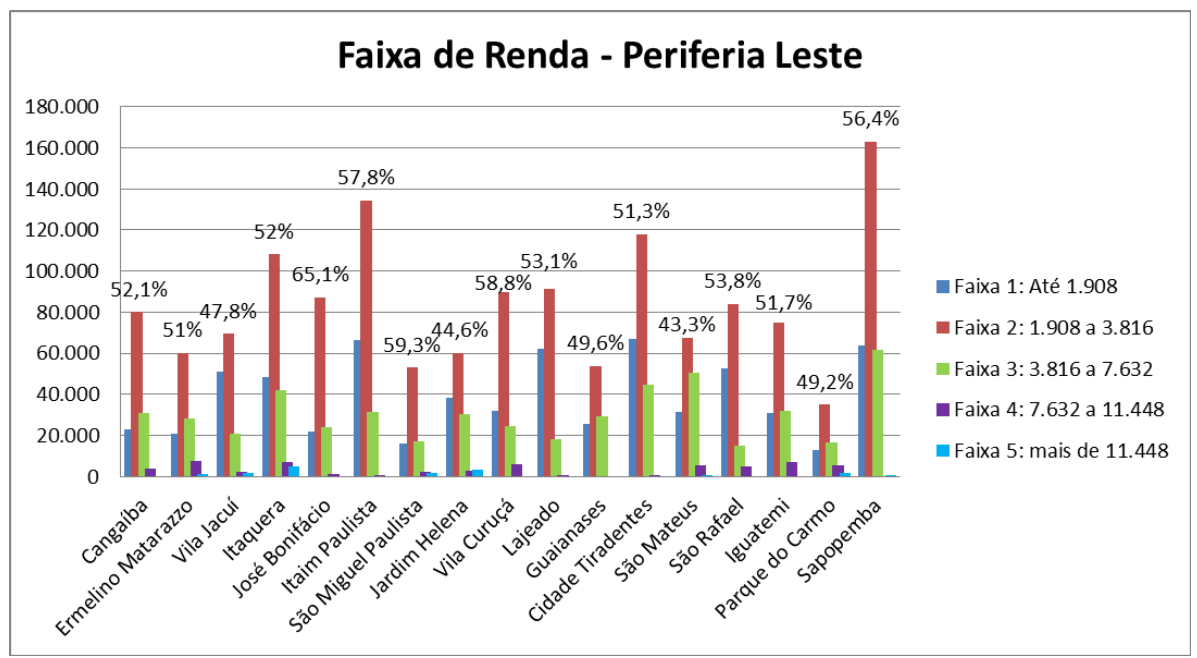

Fonte: Elaboração própria. Metrô-Pesquisa OD 2017

O espaço percebido por participantes da pesquisa mostra uma expectativa - quase nunca cumprida - de melhorias no sistema de transporte, condições de vida e reprodução que não são contempladas socialmente, precisamente pelo aspecto de que essa seria a confirmação da regra da desigualdade estrutural de nossa sociedade. Os(as) participantes que responderam os questionários destacaram ainda os seguintes aspectos:

Eu me mudaria para perto do trabalho, aliás, vou me mudar no próximo ano. Vou me mudar para diminuir o tempo que gasto com a locomoção, bem como a energia empregada em se locomover. Além disso, quero ficar mais próxima das minhas atividades de lazer, que acabam sendo na região central também, por causa do círculo de amizades do trabalho, da faculdade etc., você vai migrando para o centro. A oferta de transporte coletivo, as opções, o preço e o horário de funcionamento deveriam mudar 
e ser 24 h por dia o metrô e CPTM. Deveria ter grandes empresas e boas ofertas de emprego em todas as regiões da cidade e não apenas na região central e no novo centro (Zona Sul) (Gabriela Nogueira, 2019).

Aumentando a quantidade de transporte automaticamente a condução não fica tão lotada. Que as pessoas de nível médio e baixo tivesse mais facilidade de moradia, não apenas as pessoas de nível alto. Nós pobres só vamos para a cidade a trabalho na maioria das vezes, ou quando tem algum evento como, por exemplo, shows que não tem em nosso bairro (Jéssica Sousa, 2019).

O Metrô deveria chegar a todas as regiões da cidade, para facilitar a vida dos trabalhadores e estudantes periféricos, otimizando o tempo e contribuindo para a qualidade de vida. Que as políticas públicas cheguem firme em todos os bairros, que o periférico não precise ir até o centro para acessar teatro, cinemas e etc. A cidade deveria ser para todos e principalmente para aqueles que a constroem (Allan Cunha, 2019).

Deveria mudar no transporte a qualidade, mais variedade de opções, e que o trabalhador possa estar mais perto do emprego para que o transporte não seja tão lotado. Pensar no bem estar do trabalhador, com uma cidade que estimule o emprego mais próximo do trabalhador, com mais infraestrutura e opções de circulação dentro da cidade e da região metropolitana como um todo, e porque não a outros estados (Ireldo Alves, 2019).

Deveria haver linhas de ônibus circulares entre os bairros próximos, demora muito para chegar a alguns lugares porque é fora de mão. Como sair da minha casa e ir para o Encosta Norte, bairro próximo, mas não tem uma linha de ônibus que acessa. Ampliar a malha ferroviária para as periferias, ter trens ou metrôs circulares e transversais. Vou muito para Santo André, 
é próximo de Guaianases, mas preciso ir de trem até o Brás e depois ir sentido ABC, é uma volta que eu dou (Renata Sousa, 2019).

O espaço vivido possibilita o espaço percebido da desigualdade como nos relatos acima, ao evidenciar expectativas e como algumas delas poderiam ser realizadas no capitalismo. Quando a Gabriela Nogueira falou em mudar para próximo de seu trabalho devido os longos deslocamentos diários, ela explicitou a condição socioespacial de trabalhadores(as) de que vive nas periferias. Alguns talvez consigam mudar para perto do trabalho, mas a maioria continua vivendo o "exílio" da periferia sendo consumido por longos deslocamentos diários residência-trabalho. Fica perceptível na análise comparativa entre periferia sul e periferia leste tal como cantou o rapper GOG de que "periferia é periferia em qualquer lugar", e os Racionais $\mathrm{MC}^{\prime}$ 's de que "o mundo é diferente da ponte pra cá". Os deslocamentos externos na periferia sul chegaram a 799 mil viagens diárias enquanto que na periferia leste 788 mil, ao explicitar a mobilidade restrita dos habitantes.

Numa comparação com o centro expandido do município de São Paulo percebemos como essa área urbana tem as melhores condições de infraestrutura, transporte, emprego, comércio, etc.; além de propiciar mobilidade ampliada para quem habita esse território. 


\section{Figura 10: Deslocamentos Externos por Modo \\ Coletivo - Centro Expandido - 2017}

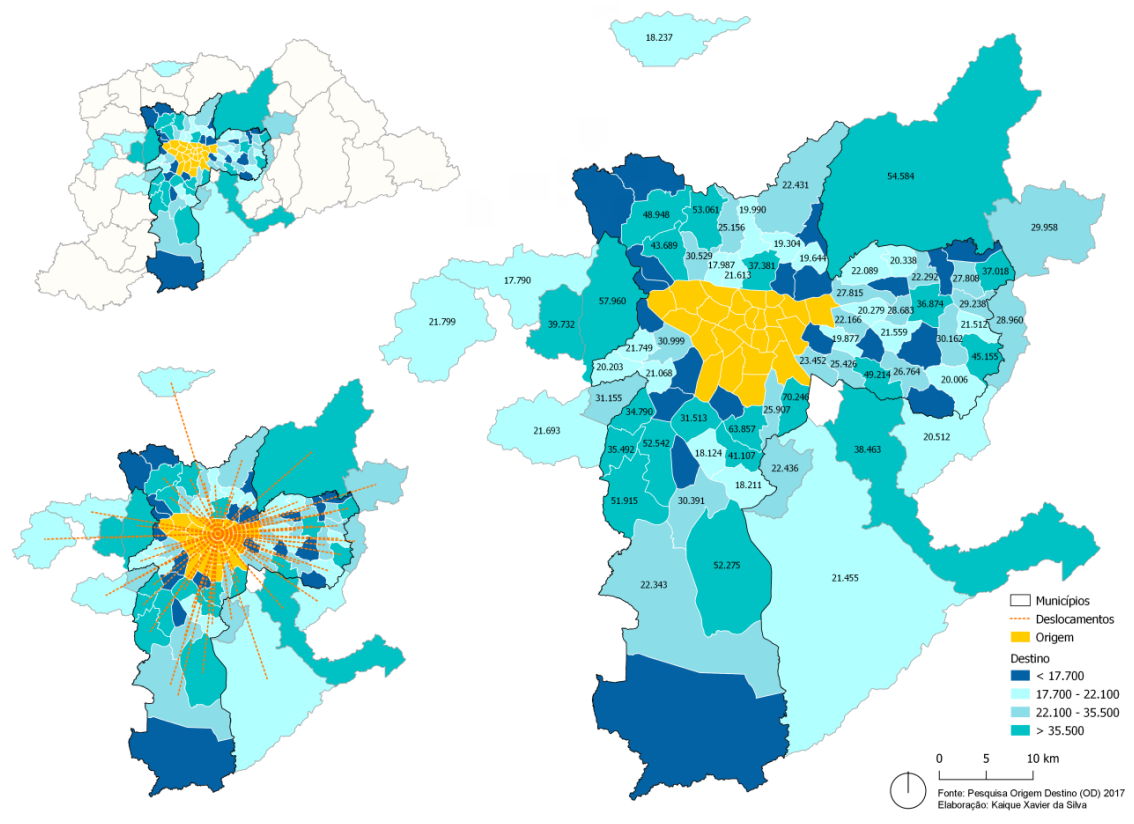

Fonte: Elaboração própria: Mapa Kaique Xavier, dados agrupados POD 2017 Sandro Oliveira.

Os 2,39 milhões de deslocamentos externos ${ }^{18}$ por modo coletivo que partem do centro expandido têm maior abrangência e alcance, tanto no que se refere à cidade de São Paulo como à RMSP, sendo isoladamente a área com maior quantidade de viagens diárias por modo coletivo (3,47 milhões) e modo individual (2,35 milhões), internos e externos. As viagens externas por modo coletivo no mapa mostram dinâmica distinta em relação às periferias: o centro expandido é a área que dispõe de uma mobilidade cotidiana ampliada porque detém a

\footnotetext{
${ }^{18}$ Centro expandido: viagens internas por Modo Coletivo foram 1,08 milhão, somada às externas, totalizaram 3,47 milhão, que somadas as 2,35 milhões do Modo Individual totalizaram 5,83 milhões de viagens diárias.
} 
melhor infraestrutura de sistemas viários de transportes, concentrando cinco linhas de metrô, quatro linhas de trens, diversos corredores de ônibus, avenidas radiais e as vias expressas das marginais Tietê e Pinheiros, e permitindo aos indivíduos que habitam mais opções de destinos e meios de transporte para sua realização em todas as direções num movimento de $360^{\circ}$ (mobilidade ampla), diferente das linhas das periferias sul e leste que perfazem o movimento limite de $90^{\circ}$ rumo ao centro (mobilidade restrita).

Destacamos quinze principais deslocamentos coletivos externos do centro expandido: Sacomã (70.246), Jabaquara (63.857), Osasco (57.960), Guarulhos (54.584), Brasilândia (53.061), Jardim São Luís (52.542), Grajaú (52.272), Jardim Ângela (51.915), Sapopemba (49.214), Jaraguá (49.949), Cidade Tiradentes (45.155), Pirituba (43.689), Cidade Ademar (41.107), Carapicuíba (39.732) e Santo André (38.463). Em todas as direções, os deslocamentos eram massivos e altos se comparados isoladamente aos territórios de subúrbios e periferias. Essa é uma das características do adensamento vertical no centro expandido, porque há muitos edifícios e torres que aumentam a demografia num território com infraestrutura viária de transporte mais desenvolvida e, por esse motivo, com localizações valorizadas que dificulta a presença de trabalhadores de baixíssima renda.

\section{Figura 11: Faixa de Renda Familiar Zona de Residência - Centro Expandido - 2017}

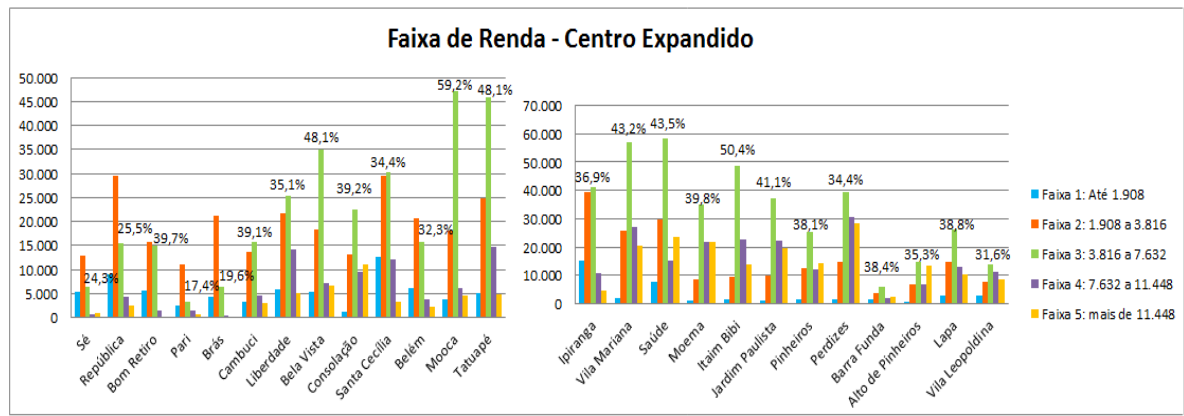

Fonte: Elaboração própria. Metrô-Pesquisa OD 2017 
Na Figura 11 a faixa 3 de renda está mais concentrada na área do centro expandido, representando a média de $39,6 \%$ da população, enquanto que as faixas 1 e 2 somadas representam $31,3 \%$. Nos distritos do centro histórico a composição de trabalhadores nas faixas 1 e 2 prepondera nos distritos da Sé $(20,5 \% ; 49,1 \%)$; República $(14,8 \% ; 48,5 \%)$; Brás (13,6\%; 65,4\%); e Pari (13,1\%; 58,4\%). A faixa 3 (renda média) prepondera na maior parte, ao mostrar a concentração da classe média nos distritos de Mooca (59,2\%), Itaim Bibi (50,4\%), Tatuapé (48,1\%), Bela Vista $(48,1 \%)$, Saúde (43,5\%), Vila Mariana (43,2\%), Ipiranga $(36,9 \%)$ e Perdizes (34,4\%). Mooca e Itaim Bibi ultrapassam mais da metade da população nessa faixa. As faixas 4 e 5 (alta e altíssima renda) são grandes em Perdizes (26,8\%; 24,7\%), Moema (24,7\%; 24,6\%), Jardim Paulista $(24,6 \% ; 21,8 \%)$, Vila Mariana $(20,4 \% ; 15,5 \%)$ e Saúde $(11,3 \%$; $17,5 \%)$.

A necessidade de viagens diárias entre moradia e trabalhoeducação resulta no tempo de deslocamento socialmente determinado pela tríplice segregação do urbano, como condição socioespacial que se desdobra para o cotidiano da mobilidade perversa imposto para maior parte da classe trabalhadora das periferias que necessita se deslocar diariamente longas distâncias, sob as condições precárias de transporte, assédio sobre as mulheres e arcando com os custos que não deveria ser dos trabalhadores, nem de estudantes que adquiriam o passe livre estudantil, nem de idosos entre 60 e 64 anos que tiveram suprimido o direito à gratuidade em fevereiro de 2021 pela Prefeitura de São Paulo e o GOVESP.

Do mesmo modo que no passado as fábricas eram o receptáculo de força de trabalho e de sua aglomeração urbana, nas últimas décadas de desenvolvimento urbano e de reprodução ampliada do capital por meio da produção do espaço, conduzida pelo setor imobiliário e por trabalhadores assalariados e precários na expansão recente da periferia, verifica-se uma dinâmica de concentração urbana mediada pela lógica 
do habitat (habitação como necessidade à sobrevivência) ${ }^{19}$. Isso mostra que há padrões distintos de acordo com a classe social que tal produção espacial visa atender, e a aglomeração via tríplice segregação do urbano solidifica uma separação entre as classes mesmo em territórios das periferias e subúrbios em São Paulo. O centro expandido, por sua vez, mostra novo padrão de aglomeração mediado pelo adensamento de torres de edifícios que se expandem como tendência geral para toda a cidade e metrópole paulista, ao evidenciar um fenômeno que é preciso apreender suas consequências por meio de sua diversidade.

David Harvey (2018) analisou e chamou a atenção para a lógica de "investimentos" nas bolsas de valores e do crédito em perspectiva de valorização futura de empresas e negócios, ao enfatizar como essa lógica de capital fictício domina o presente, precariza e compromete a reprodução da força de trabalho. Isso tem mostrado consequências para nossa relação com tempo e espaço. Por isso, ele propôs três concepções de tempo e espaço para mostrar como a situação ficará tanto mais complicada: 1) tempo-espaço absoluto, condição que corresponde ao espaço do trabalho concreto, da jornada de trabalho, da fábrica e do mais-valor absoluto envolvido na luta da extensão da jornada de trabalho; 2) tempo-espaço relativo, refere-se ao tempo e espaço do mais-valor relativo e da produtividade e intensidade variáveis do trabalho. Essa noção permite ver a localização relativa, a facilidade de acesso e os meios, custos e tempos de transportes; e 3) tempo-espaço relacional, conforme o desenvolvimento do trabalho abstrato, sendo ele a totalidade dos trabalhos concretos no tempo-espaço relacional (Harvey, 2018: p. 142).

A noção de tempo-espaço absoluto de Harvey contribui para pensar as consequências do tempo de deslocamento socialmente determinado

\footnotetext{
${ }^{19}$ Em sua crítica a urbanização capitalista, Lefebvre (2008) analisa a generalização da forma habitat (habitação como necessidade à sobrevivência) em contradição e oposição à forma habitar (apropriação do lugar para a vida), ao expor que tal logica se generalizaria com a urbanização capitalista e revelaria a zona crítica desta urbanização como um problema assentado na produção do espaço na lógica capitalista de produção.
} 
analisado aqui, porque para parte da classe trabalhadora periférica e suburbana é de 2 horas diárias em média, o que faz com que tal tempo de deslocamento se converta em extensão da jornada de trabalho por meio do tempo-espaço absoluto. Ele é absoluto para quem é consumido por jornadas de 8 a 12 horas de trabalho e ainda necessita dispor em média de 2 horas diária de deslocamento, além de estar associado à segregação entre local residência e local de trabalho decorrentes do desajuste espacial entre mercado de terra e mercado de trabalho mediado pela distância e os meios de transportes para satisfazer tal deslocamento. Em síntese, quem habita as periferias vive as condições do tempo-espaço absoluto.

O tempo-espaço relativo existe num quadro de tempo relativo e sua medida não é feita em horas trabalhadas, mas sim na produtividade e intensidade do trabalho. Em termos urbanos, mostra-se em distritos e áreas urbanas de São Paulo: destruição criadora por meio da demolição de fábricas antigas, casas e quarteirões inteiros para a produção de torres de edifícios, o que mostra o processo intenso da produção de moradias pela lógica do habitat que adensa e aglomera ainda mais a população em determinados territórios inseridos nos vetores de valorização imobiliária, e isso exige mais escolas, saúde, transporte e outros serviços urbanos nessas localidades, além de maior circulação de seus habitantes para outras áreas da metrópole onde se concentram os postos de emprego, universidades e outros serviços. O tempo-espaço relativo pode ser entendido nas diferentes condições de moradia e deslocamentos de indivíduos entre origem e destino, diferenciado entre membros das classes média e trabalhadora de uma mesma área urbana em termos relativos. Quem habita os subúrbios vive as condições do tempo-espaço relativo, porque estão na faixa intermediária entre as periferias e o centro expandido (não analisado nesse artigo).

Por sua vez, o tempo-espaço relacional resulta do avanço do capital e do trabalho abstrato na produção do espaço, seja pela produção de imóveis, viário e sistema de transporte, o que promove a integração entre diferentes espaços, porém, amplia as formas de segregação entre

\begin{tabular}{l|l}
40 & Condição socioespacial e (i)mobilidade urbana...
\end{tabular} 
outros espaços, porque sua expansão se desenvolve pelas vias da abstração do valor de troca e do trabalho abstrato do espaço concebido e cindido dos demais espaços vividos e percebidos. Esse tempo-espaço é relacional porque consiste em considerar a condição socioespacial não apenas por indivíduos, mas pelas relações de classes a partir do espaço urbano produzido, reproduzido e apropriado como expressão da estrutura social. Essa área urbana da metrópole que se insere diretamente no tempo-espaço relacional, por reunir maior concentração de capital, trabalho e riqueza produzidos na forma de equipamentos públicos e privados, sistemas viários e também por concentrar maior trabalho abstrato não apenas na geração de valor, mas na riqueza dos espaços no sentido de apropriação das classes sociais que ali circulam e se apropriam dessa produção.

A guisa da conclusão, a desigualdade urbana entre as áreas das periferias leste e sul, se comparadas aos subúrbios e centro expandido, é resultado do processo de urbanização em que produção e reprodução do espaço se fizeram na lógica capitalista, que desenvolveu espaços diferenciados entre as classes não apenas por renda, mas por bairros, distritos e áreas oriundas da tríplice segregação. No centro expandido há uma mobilidade ampla em todas as direções, enquanto que na periferia há uma mobilidade restrita majoritariamente para o centro. Não por acaso, a periferia segue sangrando, sofrendo e agonizando nos deslocamentos diários e tais condições de transporte e mobilidade caracterizam esse "mundo diferente da ponte pra cá" pela condição socioespacial da classe trabalhadora periférica e mostra, para aqueles que negam a existência das classes sociais, que a formação das classes perpassa a tríplice segregação urbana e o tempo de deslocamento que se tornou espaço vivido-percebido e permite experiências de solidariedade e contribui no fazer-se da classe trabalhadora não apenas na circulação ao trabalho, mas no tecido da vida das relações espaçotempo, tal como no bonito e paradoxal relato vivido no transporte: 
Uma vez eu acordei com um bolo no meu colo e todo mundo cantando parabéns pra mim dentro do ônibus. Eu acordei assustada e vi um bolo, refrigerante e tudo. [...] Outro dia tinha um monte de bexiga! Aí eu falei "é aniversário de quem? Do cobrador!". Aí todo mundo levou alguma coisa e um monte de bexiga.

(Vera Santos da Silva, grupo focal, 2019).

\section{Considerações finais do artigo}

Como vimos na breve análise neste artigo, mobilidade e imobilidade urbana não podem ser analisadas em si mesmas, já que sua crise expressa um conjunto de relações de classes e determinações sociais, políticas e econômicas que são oriundas do modelo de urbanização rodoviarista que predominou no Brasil. Tal urbanização desenvolveu uma distância espacial da periferia em relação aos centros geográfico do urbano na metrópole onde se concentram os empregos, serviços e equipamentos urbanos expressando a distância entre as classes sociais; fez crescer o tempo de deslocamento pelo crescimento das cidades e metrópole ao criar condições socioespaciais de diferenciação das classes pelo cotidiano da mobilidade perversa para os trabalhadores; e transformou o meio de transporte, que deixou de ser encarado como direito social, em meio de acumulação e espoliação urbana, visto como "serviço" que pode ser operado por empresas privadas, por exemplo.

Considerando que os sistemas viários e de transporte estão organizados para levar os trabalhadores às localizações que concentram os empregos; que as localizações de grande parte desses trabalhadores estão distantes nas periferias onde os preços do aluguel e da renda da terra são mais baixos; de que a noção de periferia foi apropriada por trabalhadores periféricos a partir dos espaços percebidos e vividos que lhe atribuiu um sentido de classe por meio do modo de vida; os estudos sobre mobilidade urbana e transporte não podem deixar de prescindir do entendimento das relações de classes por meio da condição socioespacial como mais uma camada da desigualdade urbana.

$\overline{42}$ Condição socioespacial e (i)mobilidade urbana... 
Para apreender as determinações da condição socioespacial é fundamental considerar a tríplice segregação do urbano (socioespacial, étnico-racial e urbana/territorial) como demonstrada nesse artigo; os processos de constituição da urbanização rodoviarista por meio do lobby da tríade industrial automotiva, petrolífera e construção civil; a análise das classes nos territórios da periferia, do subúrbio e do centro expandido/quadrante sudoeste; e a tríade tempo-espaço absoluto, tempoespaço relativo e tempo-espaço relacional para compreender a diferenciação espacial entre as classes sociais no urbano.

Como já se tornou referência no Movimento Passe Livre de que uma cidade desenvolvida não é aquela que os trabalhadores pobres andam de automóveis, mas aquela em que os ricos andam de transporte público, a ampliação do sistema metroferroviário, criação de linhas de ônibus circulares e entre bairros na periferia, estatização do transporte e implementação a tarifa zero, como no município de Maricá no estado do Rio de Janeiro, são políticas sociais que permitiriam aos trabalhadores circular com menos barreiras e se apropriarem de parte das riquezas produzidas socialmente e distribuídas desigualmente na metrópole nas cidades e metrópoles brasileiras, ao amenizar os efeitos do cotidiano da mobilidade perversa em decorrência da tríplice segregação do urbano.

\section{Referências}

AMORIM, Henrique; SILVA, Jair Batista da Silva (org.). Classes e luta de classes: Novos questionamentos. São Paulo: Annablume, 2015.

AMORIM, Henrique; SOUZA, Davisson Cangussu de (org.). As classes sociais no início do século XXI. São Paulo: Annablume, 2017.

BOLAFFI, Gabriel. "Habitação e urbanismo: O problema e o falso problema". In.: MARICATO, Ermínia (org.). A produção capitalista da casa (e da cidade) no Brasil industrial. São Paulo: Alva-Omega, 1982. 
CARLOS, Ana Fani Alessandri. A condição espacial. São Paulo: Contexto, 2018.

CHASIN, José. A miséria brasileira - 1964 - 1994: Do golpe militar à crise social. Santo André: Ad Hominem, 2000.

D'ANDREA, Tiarajú Pablo. Nas tramas da segregação: O real panorama da polis. São Paulo: FFLCH USP, Dissertação de mestrado, 2008.

D'ANDREA, Tiarajú Pablo. A formação dos sujeitos periféricos: Cultura e Política na periferia de São Paulo. São Paulo: FFLCH USP, Tese de Doutorado, 2013.

D'ANDREA, Tiarajú Pablo. "Contribuições para a definição dos conceitos periferia e sujeitas e sujeitos periféricos". In: Revista Novos Estudos CEBRAP, São Paulo, v.39, n. 01, p. 19-36, 2020.

DAVIS, Angela. Mulheres, raça e classe. São Paulo: Boitempo, 2016.

FERNANDES, Florestan. Capitalismo dependente e classes sociais na América latina. São Paulo: Zahar, 1973.

FIX, Mariana. São Paulo cidade global: Fundamentos financeiros de uma miragem. São Paulo: Boitempo, 2007.

GALVÃO, Olímpio J.A. “Desenvolvimento dos transportes e integração regional no Brasil - uma perspectiva histórica". In: Planejamento e Políticas Públicas, n. 13, p. 183-214, jun. de 1996.

GONZALEZ, Lélia. Por um feminismo afro-latino-americano. Rio de Janeiro: Zahar, 2020.

HARVEY, David. A produção capitalista do espaço. São Paulo: Annablume, $2^{\mathrm{a}}$ Ed., 2006.

HARVEY, David. O novo imperialismo. São Paulo: Boitempo, 2014.

\begin{tabular}{l|l}
44 & Condição socioespacial e (i)mobilidade urbana...
\end{tabular} 
HARVEY, David. A loucura da razão econômica: Marx e o capital do século XXI. São Paulo: Boitempo, 2018.

KOWARICK, Lúcio. A espoliação urbana. São Paulo: Paz e Terra, 1979.

LEFEBVRE, Henri. A reprodução das relações de produção. Porto: Escorpião, 1973.

LEFEBVRE, Henri. La production de l'espace. 4e éd. Paris: Éditions Anthropos, 2000.

LEFEBVRE, Henri. A revolução urbana. Belo Horizonte: Editora UFMG, 2008.

LEFEBVRE, Henri. O direito à cidade. São Paulo: Centauro Editora, 2009.

LEFEBVRE, Henri. Espaço e política: $\mathrm{O}$ direito à cidade II. $2^{\mathrm{a}}$ ed. rev. Belo Horizonte: Editora UFMG, 2016.

LIPIETZ, Alain. "Fordismo, fordismo periférico e metropolização". In.: Ensaios FEE. Porto Alegre, v. 10, n. 2, 1989. Disponível em: https://revistas.fee.tche.br/index. php/ensaios/article/view/1381. Acessado em: 09 jan. 2020.

MARICATO, Ermínia (org.). A produção capitalista da casa (e da cidade) no Brasil industrial. São Paulo: Alva-Omega, 1982.

MARICATO, Ermínia (org.). Metrópole na periferia do capitalismo. São Paulo: Hucitec, 1996.

MARICATO, Ermínia (org.). Para entender a crise urbana. São Paulo: Expressão Popular, 2015.

MARINI, Ruy Mauro. Dialética da dependência. Petrópolis: Vozes, 2000.

MARQUES, Eduardo. (Org). As políticas do urbano em São Paulo. São Paulo: Editora Unesp; Centro de Estudos da Metrópole, 2018. 
MARTINS, José de Souza. Subúrbio - Vida cotidiana e história no subúrbio da Cidade de São Paulo. São Caetano do Sul: Hucitec, 1992.

MARTINS, José de Souza. “Depoimento - José de Souza Martins". In: Espaço \& Debates, Revista de Estudos Regionais e Urbanos, ano XVII, nº 42, p. 75-84, 2001.

MARX, Karl. O capital: Crítica da economia política. Livro I. São Paulo: Boitempo, 2013.

MARX, Karl. O capital: Crítica da economia política. Livro II. São Paulo: Boitempo, 2014.

PRADO JÚNIOR, Caio. História econômica do Brasil. São Paulo: Brasiliense, 16 ${ }^{\mathrm{a}}$ ed., 1973.

PRADO JÚNIOR, Caio. Formação do Brasil contemporâneo. São Paulo:

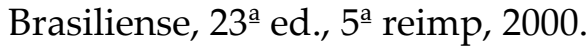

OLIVEIRA, Sandro Barbosa de. A condição socioespacial da classe trabalhadora: Transporte e cotidiano da mobilidade perversa na metrópole de São Paulo. Campinas: IFCH UNICAMP, Tese de Doutorado, 2020.

SADER, Eder. Quando novos personagens entram em cena: Experiências, falas e lutas dos trabalhadores da Grande São Paulo 1970-80, Rio de Janeiro, Paz e Terra, 1988.

SANTINI, Daniel. Passe Livre: As possibilidades da tarifa zero contra a distopia da uberização. São Paulo: Autonomia Literária/ Fundação Rosa Luxemburgo, 2019.

SILVA, Ricardo Barbosa da. Mobilidade precária na metrópole de São Paulo, São Paulo, Annablume, 2016.

SINGER, Paul. Economia política da urbanização. São Paulo: Brasiliense, $2^{\underline{a}}$ ed., 1975. 
SOUZA, Jessé. A elite do atraso: Da escravidão à lava jato. Rio de Janeiro: Leya, 2017.

THOMPSON, Edward Palmer. A formação da classe operária inglesa. Rio de Janeiro, Paz e Terra, 1997.

VASCONCELLOS, Eduardo A. Circular é preciso, viver não é preciso. São Paulo: Annablume-Fapesp, 1999.

VASCONCELLOS, Eduardo A. Políticas de Transporte no Brasil: A construção da mobilidade excludente. São Paulo: Manoele, 2014.

VILLAÇA, Flávio. Espaço intra-urbano no Brasil. São Paulo: Stud. Nobel, 1998.

VILLAÇA, Flávio. Reflexões sobre as cidades brasileiras. São Paulo: Studio Nobel, 2012. 